FEDERAL RESERVE BANK of ST. LOUIS

\section{RESEARCH DIVISION} Working Paper Series

\title{
Parenthood and Productivity of Highly Skilled Labor: Evidence from the Groves of Academe
}

\author{
Matthias Krapf, \\ Heinrich W. Ursprung \\ and \\ Christian Zimmermann
}

\author{
Working Paper 2014-001A \\ https://doi.org/10.20955/wp.2014.001
}

January 2014

\author{
FEDERAL RESERVE BANK OF ST. LOUIS \\ Research Division \\ P.O. Box 442 \\ St. Louis, MO 63166
}

The views expressed are those of the individual authors and do not necessarily reflect official positions of the Federal Reserve Bank of St. Louis, the Federal Reserve System, or the Board of Governors.

Federal Reserve Bank of St. Louis Working Papers are preliminary materials circulated to stimulate discussion and critical comment. References in publications to Federal Reserve Bank of St. Louis Working Papers (other than an acknowledgment that the writer has had access to unpublished material) should be cleared with the author or authors. 


\title{
Parenthood and Productivity of Highly Skilled Labor: Evidence from the Groves of Academe
}

\author{
Matthias Krapf, Heinrich W. Ursprung, and Christian Zimmermann*
}

January 11, 2014

\begin{abstract}
We examine the effect of pregnancy and parenthood on the research productivity of academic economists. Combining the survey responses of nearly 10,000 economists with their publication records as documented in their RePEc accounts, we do not find that motherhood is associated with low research productivity. Nor do we find a statistically significant unconditional effect of a first child on research productivity. Conditional difference-in-differences estimates, however, suggest that the effect of parenthood on research productivity is negative for unmarried women and positive for untenured men. Moreover, becoming a mother before 30 years of age appears to have a detrimental effect on research productivity.
\end{abstract}

Keywords: Fertility, research productivity, gender gap, research productivity, life cycle.

JEL Classification Codes: J13, I23, J24.

\footnotetext{
*Krapf: University of Zurich (matthias.krapf@business.uzh.ch); Ursprung: University of Konstanz (heinrich.ursprung@uni-konstanz.de); Zimmermann: Federal Reserve Bank of St. Louis (zimmermann@stlouisfed.org). We are grateful to Simone Balestra, Maria Canon and Dan Hamermesh for helpful comments. The views expressed are those of the individual authors and do not necessarily reflect official positions of the Federal Reserve Bank of St. Louis, the Federal Reserve System, or the Board of Governors.
} 


\section{Introduction}

Over the past 50 years the gender wage gap has substantially narrowed, mainly because women are now better educated and their labor market participation has become more continuous (Goldin, 1989; Weichselbaumer and Winter-Ebmer, 2005). However, in terms of achieving leading positions, women still lag behind, indicating that women still have a disadvantage in pursuing challenging professional careers. One possible explanation for this disparity in catching up is that the provision of institutionalized child care has helped low-skilled women with standard working times to better combine wage labor with looking after their children, whereas highly skilled women, whose careers require an ongoing preoccupation with the matters of their profession, benefit less from child care provisions and are therefore less able to do justice to the demands of a family.

In this paper, we explore the intricate relationship between parenthood and the supply of highly skilled labor by investigating the effect of pregnancy and parenthood on the productivity of academic economists. Scientists provide an eminently suitable profession for our purposes because well-established and generally accepted measures of research productivity are available, whereas for most other highly skilled professionals, such as managers, engineers, surgeons, top officials, and so on, comparable productivity measures are either not available or not recorded. Our focus is on female academic economists, but we also investigate how male economists are affected by fatherhood.

Our data are from a survey sent to all economists with an account with the research platform RePEc (Research Papers in Economics). This platform records the research output of some 30,000 economists from 75 countries. About 10,000 economists answered our anonymous survey. Matching the survey answers with the responders' publication records yields a panel dataset of more than 150,000 annual observations of career and family situation details. The sample size of our dataset thus exceeds that of other studies of research productivity by an order of magnitude.

Since parenthood among professionals is usually planned, the identification of the effects of parenthood on research productivity is not simple. We therefore begin our analysis by simply documenting career patterns while making no attempt to derive causal relationships. The descriptive statistics do, however, immediately suggest that reverse causality is indeed likely to be an issue: Our data suggest that economists with two or more children are more productive than economists with only one child or no children, although the difference is not statistically significant. Apart from the obvious effects of parenthood on labor supply and productivity, we thus need to contend with a possible reverse causality effect running from productivity to family structure. If the decrease in productivity resulting from the additional burden of parenthood is as strong as the increase that may result from responsible parents with a stronger commitment to work, parenthood does not decrease labor productivity simply because family planning is selective in the 
sense that only parents who know that they will be able to cope with the additional burden decide to have children.

\section{Related literature}

A substantial part of the literature on gender gaps in the academic labor market emphasizes that women are more likely than men to take non-ladder teaching positions or to leave academia when they have children (Joecks, Pull, and Backes-Gellner, 2013; Mason, Wolfinger, and Goulden, 2013). The empirical evidence, however, provides far from a uniform picture. Hunt (2010), for example, finds that family-related constraints play at best a minor role in women's decision to leave science and engineering. Our analysis does not investigate this effect of parenthood. We only observe "survivors,"- that is, those with $\mathrm{PhDs}$ in economics who stayed in academia - and investigate the extent to which their productivity is affected by parenthood. Of course, evaluating the total effect of childbirth and parenthood on academic career paths requires consideration of both channels of influence.

The literature investigating the academic careers of survivors has paid special attention to the gender gaps in wages, promotion, and research productivity. The gender wage gap in academia has narrowed over time but still persists (Kahn, 1995; Faggian and Della Giusta, 2008). Controlling, however, for the prestige of the PhD-granting institution, experience, seniority, and especially for research productivity, substantially reduces the net wage gap (Ward, 2001) and may even close it altogether (Gibson, Anderson, and Tressler, 2012). This finding is well in line with the results of similar studies on nonacademic groups of highly educated workers such as college graduates (Black, Haviland, Sanders, and Taylor, 2008) and MBAs (Bertrand, Goldin, and Katz, 2010). Waldfogel (1998) investigates the family wage gap (i.e., the wage differential between women with and without children). While the gender wage gap has substantially narrowed, the family wage gap has widened in the United States: Women with children face a wage penalty of around $10 \%$ to $15 \%$ compared with women without children. Waldfogel (1998) especially highlighted the importance of maternity leave coverage in explaining cross-country differences in the family wage gap: The family wage gap was smaller in countries that provide maternity leave coverage.

Perhaps more troublesome than the gender wage gap are the effects of gender and family formation on academic promotion (Kahn, 1993). At the beginning of their academic careers, women are not disadvantaged because they are women; but they are less likely than men to obtain tenure-track assistant professorships when they are married and do have children. Married women have a $12 \%$ lower probability of obtaining a tenure-track position than married men and a $22 \%$ lower probability than childless women (Wolfinger, 
Mason, and Goulden, 2008). When they are eligible for tenure, however, women are also disadvantaged for reasons unrelated to family formation. Compared with other academic disciplines, female economists are even more likely to remain untenured; and if they do obtain tenure, it occurs a year later and less often at their original academic institution than their male peers (Ginther and Kahn, 2004). Women suffer a gender penalty of $21 \%$ for promotion to full professorship. Children play no role, but marriage increases the likelihood of promotion by 23\% for men and women (Wolfinger, Mason, and Goulden, 2008). To be sure, this result reflects the institutional setting of the American academic labor market and was derived without controlling for research productivity. Schulze, Warning, and Wiermann (2008) investigate the probability of being offered a full professorship in German language countries where obtaining tenure is concomitant with promotion to full professor. Their encompassing sample consists of successful and unsuccessful candidates in economics and business administration. They find that children have no effect and being married has a positive effect on being offered a full professorship. More importantly, when controlling for research productivity, they find that women do not suffer a disadvantage at that career stage. Plümper and Schimmelfennig (2007) arrive at a similar result. They observe that in the German political science profession, mothers are less likely to become full professors because they have fewer publications. But controlling for research productivity, it transpires that women are more likely to be offered a full professorship and they tend to be promoted at a younger age than their male competitors. Moreover, the findings of Plümper and Schimmelfennig (2007) suggest that fathers, compared with mothers, tend to be discriminated against at that stage of their career.

The gender gap in economic research productivity is well documented but has narrowed substantially for younger cohorts (McDowell, Singell, and Stater, 2006) and for females who are indeed active researchers (Rauber and Ursprung, 2008). The gender gap is, of course, crucial for the relationship between parenthood and career success in academia. This is so because, on the one hand, research productivity is the key determinant for academic advancement (Hamermesh, Johnson, and Weisbrod, 1982; Sauer, 1988; Gibson, Anderson, and Tressler, 2012). On the other hand, family formation is likely to have a decided influence on productivity. Kaufman and Uhlenberg (2000) examine how the work effort of men and women changes following parenthood. Women work less, while some men work less (involved-father model) and others work more (good-provider model). Related survey evidence presented by Rhoads and Rhoads (2012) suggests that male professors with children younger than 2 years of age are less involved in child care than female professors even if they, the males, profess to assume a nontraditional gender role. Finally, Schiebinger, Henderson, and Gilmartin (2008) provide comprehensive survey statistics that describe the impact of dual-career partnering on hiring, retention, professional attitudes, and work culture at U.S. universities. 
With parenthood now generally planned, potential reverse causality needs to be considered in any attempt to disentangle the mutual relationship between parenthood and productivity. Adda, Dustmann, and Stevens (2011) model and estimate the complex interaction of career and fertility choices. They find that women in high-growth/high-atrophy occupations are less likely to have children, and if they do, they have them at an older age. The authors estimate a structural model that suggests that desired fertility and ability are indeed positively correlated. This result is well in line with the study by Joecks, Pull, and Backes-Gellner (2013) who find a positive correlation between academic output and fertility for a sample of economists and business economists affiliated with Austrian, German and Swiss universities.

Establishing a causal link between motherhood and labor market outcomes requires a plausible identification strategy that addresses the endogeneity of fertility. Angrist and Evans (1998), for instance, use as their instrument a dummy variable indicating whether the first two children in a family are of the same sex, because in that case parents are more likely to have additional children. Various authors have used biological fertility shocks to estimate the causal effect of motherhood on labor market outcomes. Aguero and Marks (2008) use infertility. Markussen and Strøm (2013) use miscarriages. And Miller (2011) estimates the effects of the timing of motherhood on mothers' earnings and hours worked using dummy variables indicating whether a woman had a miscarriage before her first child, became pregnant despite the use of contraceptives, and the time span between the first conception attempt and the first birth. Cristia (2008) addresses the endogeneity problem using a sample of women who sought help to become pregnant and then compares those women who actually gave birth with those who did not.

We have chosen the method of propensity score weighting on observables to unravel the endogeneity problem. A related study that estimates the effect of motherhood on wages using matching is that of Simonsen and Skipper (2006). In a large Danish dataset, women who have given birth are classified as treated and childless women are used as controls. The authors condition on the women's age, type of education, number of siblings, and years of schooling. Distinguishing between total wage costs and direct causal effects, they find negative net effects and small negative or statistically insignificant causal effects.

We use Abadie's (2005) semiparametric difference-in-differences estimator. This estimator combines standard difference-in-differences estimation with selection on observables techniques. Abadie suggests using before-treatment characteristics as so-called confounding variables. In contrast to conventional difference-in-differences estimators, the assumption is not that the outcome for the treated and the controls would have followed similar paths in the absence of treatment, but that they would have-conditional on these confounding factors. This is the "unconfoundedness" assumption. The two-step estimat- 
ing procedure is discussed in some detail in Section 5.1. In a nutshell, it can be described as follows. In the first step, the propensity scores that predict receiving the treatment are derived nonparametrically from the confounding factors. In the second step, the propensity scores are used to match the economists from the treatment and control groups to estimate the treatment effects.

\section{Data}

\subsection{The survey}

The data for this study were gathered with a questionnaire survey (see Appendix A) sent to all economists registered with the RePEc Author Service (https://authors.repec.org/). RePEc is an initiative targeted at improving the dissemination of research in economics. It encompasses several projects. One, the RePEc Author Service, allows authors to register and build a portfolio of their works published in outlets indexed by RePEc. At the time of the survey, about 1,500 publishers (including commercial publishers, international organizations, and economics departments at universities) listed 1.3 million works.

An invitation to answer the survey was sent on January 31, 2012 and the following days to all 30,978 authors registered at the time. Those known to be deceased or to have an obsolete email address in the syste were not contacted. A reminder was sent on March 13, 2012 to those who had not responded yet. A total of 10,060 authors responded; this corresponds to a response rate of $32.5 \%$. Each response to the survey was linked to the publication records of the author; the records include the year of publication and the impact factor of the publication outlet. Some responses needed to be dropped-for example responses of economists who had only working papers in their records. We were left with 9,939 individuals. As RePEc also computes rankings of economists, we can also use this information. We thus have much more information about academic work baggage than any preceding study.

As shown in Table 1, 76\% of the economists who responded to the survey were academics, $12 \%$ worked for governments, $5 \%$ for policy institutes, and $4 \%$ in the private sector; $4 \%$ did not specify their affiliations. Respondents affiliated with universities had longer careers on average, which is why the share of university affiliations is higher among individual-year observations than among individual respondents.

One possible concern may be selection bias, first in terms of economists registered with RePEc and then in terms of registered economists who answered the survey. It is difficult to compare economists who are registered with those who are not. However, there is reason to believe that RePEc registrations are quite comprehensive: Collectively, the American Economic Association, the European Economic Association, and the Econo- 
Table 1: AfFiliations

\begin{tabular}{lrrrr}
\hline \hline & \multicolumn{2}{c}{ Individuals } & \multicolumn{2}{c}{ Panel } \\
Workplace & Frequency & Percent & Frequency & Percent \\
\hline Phd-granting & 6,837 & 68.79 & 112,356 & 72.93 \\
Masters-granting & 500 & 5.03 & 6,672 & 4.33 \\
Bachelor-granting & 186 & 1.87 & 2,949 & 1.91 \\
\hline University total & 7,523 & 75.69 & 121,977 & 79.18 \\
\hline Government & 1,183 & 11.90 & 14,824 & 9.62 \\
Policy institute & 480 & 4.83 & 5,921 & 3.84 \\
Private sector & 351 & 3.53 & 4,399 & 2.86 \\
No information & 402 & 4.04 & 6,936 & 4.50 \\
\hline Total & 9,939 & 100.00 & 154,057 & 100.00 \\
\hline \hline
\end{tabular}

metric Society have about 26,000 members, including many multiple memberships. The "membership" in RePEc easily exceeds this and thus appears to be quite comprehensive. Another indicator is that $88 \%$ of the top 1,000 economists listed in Coupé (2003) are registered in RePEc.

We have more information regarding a possible participation bias. While RePEc does not collect gender information, one can infer gender from first names. When in doubt, RePEc also searches the web for pictures. According to this criterion, $22.9 \%$ of the survey respondents are female, compared with $14.6 \%$ of nonrespondents. It is not surprising that women were more inclined to respond. However, this may have compensated another bias relating to the fact that women seem less likely to register with RePEc. Indeed, the proportion of females in RePEc (17.2\%) is markedly below all estimates of the proportion of females in the economics profession (Ginther and Kahn, 2004).

With respect to the distribution of respondents according to their RePEc ranking, we observe that the response rate is higher for the best $50 \%$, the average rank of respondents being 14,131 versus 16,388 for nonrespondents. The exception to this rule are the top 1,000 economists, of whom 330 responded. Respondents have on average 10 articles to their credit, compared with 8 for nonrespondents. There is no significant difference in the career age of respondents and nonrespondents; on average, both had their first publication in 1999.

\subsection{Research productivity measures}

We use four different measures of research productivity. All four measures are qualityweighted publication indices - that is, we record each author's publications and assign these publications a date (year) and a weight that corresponds to the quality of the respective publication outlet. Arriving at a specific productivity index requires identification of 
a list of admissible publication outlets, a corresponding vector of quality weights, and a scheme for dating the admissible publications.

Our four measures of annual research productivity are specified as follows:

(1) The RF index uses all journals recorded in RePEc and assigns these publications RePEc's own recursive impact factor (see Zimmermann, 2012; Seiler and Wohlrabe, 2011) and the date of publication of the final version. If a paper was first published as a working paper and later in a journal, RF thus uses the journal publication date and the journal's recursive recursive impact factor as measured by RePEc. The $F$ in RF thus refers to the final version.

(2) The RW index differs from the RF index only by the dating scheme. Here we date all publications by the year in which they first appear in RePEc. The W in RW thus refers to the date of the working paper version if such a version is recorded in RePEc. The quality weight, however, refers to the quality of the journal if the paper has been published by a RePEc-indexed journal. We have not collected information about research that appeared only as a working paper and was never published in a journal.

(3) The CF index is based on the journal list used by Combes and Linnemer (2010) that is, all journals indexed by the American Economic Association's electronic bibliography EconLit. The CF indexuses the journal quality index CLm proposed by Combes and Linnemer (2010), and the dates of the journal publication. Since RePEc is the data source, we were able to assign only CLm journal quality weights to articles that appeared in journals included in both the RePEc and the CombesLinnemer list.

(4) Finally, the CW index differs from the CF index only by using the publication date of the first working paper version of the journal article if such a version is recorded by RePEc.

The RW and CW indices are better suited for pinpointing when the research was actually conducted. An alternative strategy to date the genesis of a piece of research was used by Kim, Morse, and Zingales (2009), who used journal-specific and year-specific publication lags (provided by Ellison, 2002) to estimate the year in which the research was actually undertaken. Compared with the RF and RW indices, the CF and CW indices use a smaller set of admissible publication outlets because RePEc is our data source. We have information about articles if and only if they were published in a journal listed in RePEc, and RePEc recursive impact factors are available for all these journals. The CF and CW indices are available for most, but not all, of these journals because not all journals listed in RePEc are also included in EconLit. RF and RW are therefore more comprehensive, 
Table 2: SuRveY: Descriptive Statistics

\begin{tabular}{lccc}
\hline \hline Variable & Observations & Mean & Std. Dev. \\
\hline Number of children & 9,015 & 1.3986 & 1.1705 \\
\# children if children present & 6,384 & 1.9749 & 0.8923 \\
\# children women & 2,578 & 1.1575 & 1.0531 \\
\# children women w/ children & 1,665 & 1.7922 & 0.7612 \\
\# children men & 6,411 & 1.4929 & 1.2001 \\
\# children men w/ childrens & 4,696 & 2.0381 & 0.9247 \\
Age at 1st birth female & 1,582 & 31.9248 & 4.2511 \\
Age at 1st birth male & 4,430 & 32.5011 & 5.1114 \\
Career age 1st birth female & 1,547 & 0.3116 & 6.4024 \\
Career age 1st birth male & 4,311 & 0.8671 & 6.8942 \\
\hline \hline
\end{tabular}

Notes: 9,939 responses in total.

provide, however, a noisier output measure. As shown in Section 4.2, this additional noise leads to higher standard errors when RF and RW are used instead of CF and CW.

\section{Descriptive evidence}

\subsection{Descriptive statistics}

Table 2 shows some descriptive statistics. Of our 9,939 respondents, 9,015 specified how many children they had: 6,384 of them had children. Conditional on being a parent, the average number of children is slightly higher among male economists than among female economists: A father in our sample has 2.0 children on average, while a mother has 1.8 children on average. Table 3 shows the distribution of how many children respondents said they had and Figure 1 shows the distribution of age at first birth. Table B.1 (see Appendix B) shows additional descriptive statistics for the distribution of countries in which respondents received their doctorate, a variable we did not use in our analysis.

\subsection{Career cycles in research productivity}

In this section, we present fixed effect Poisson quasi-maximum likelihood estimates (Hausman, Hall, and Griliches, 1984) of life cycles in research productivity as measured by the $\mathrm{CW}$ index. Even though our dependent variable, the quality-weighted number of publications, is not a count variable, Poisson estimates are consistent if the conditional mean is correctly specified (Santos Silva and Tenreyro, 2006). One advantage of Poisson estimation is that coefficients close to zero can be interpreted as percentage changes. The 
Table 3: The Distribution of Number of CHILDREN

\begin{tabular}{lcccc}
\hline \hline \multirow{2}{*}{$\begin{array}{l}\text { Number of } \\
\text { children }\end{array}$} & \multicolumn{2}{c}{ Women } & \multicolumn{2}{c}{ Men } \\
\hline Unspecified & 222 & 7.93 & 660 & 9.33 \\
0 & 913 & 32.61 & 1,715 & 24.25 \\
1 & 630 & 22.50 & 1,357 & 19.19 \\
2 & 799 & 28.54 & 2,223 & 31.44 \\
3 & 198 & 7.07 & 813 & 11.50 \\
4 & 31 & 1.11 & 213 & 3.01 \\
5 & 4 & 0.14 & 63 & 0.89 \\
More & 3 & 0.11 & 27 & 0.38 \\
\hline Total & 2,800 & 100.00 & 7,071 & 100.00 \\
\hline \hline
\end{tabular}

Notes: 9,939 responses in total.
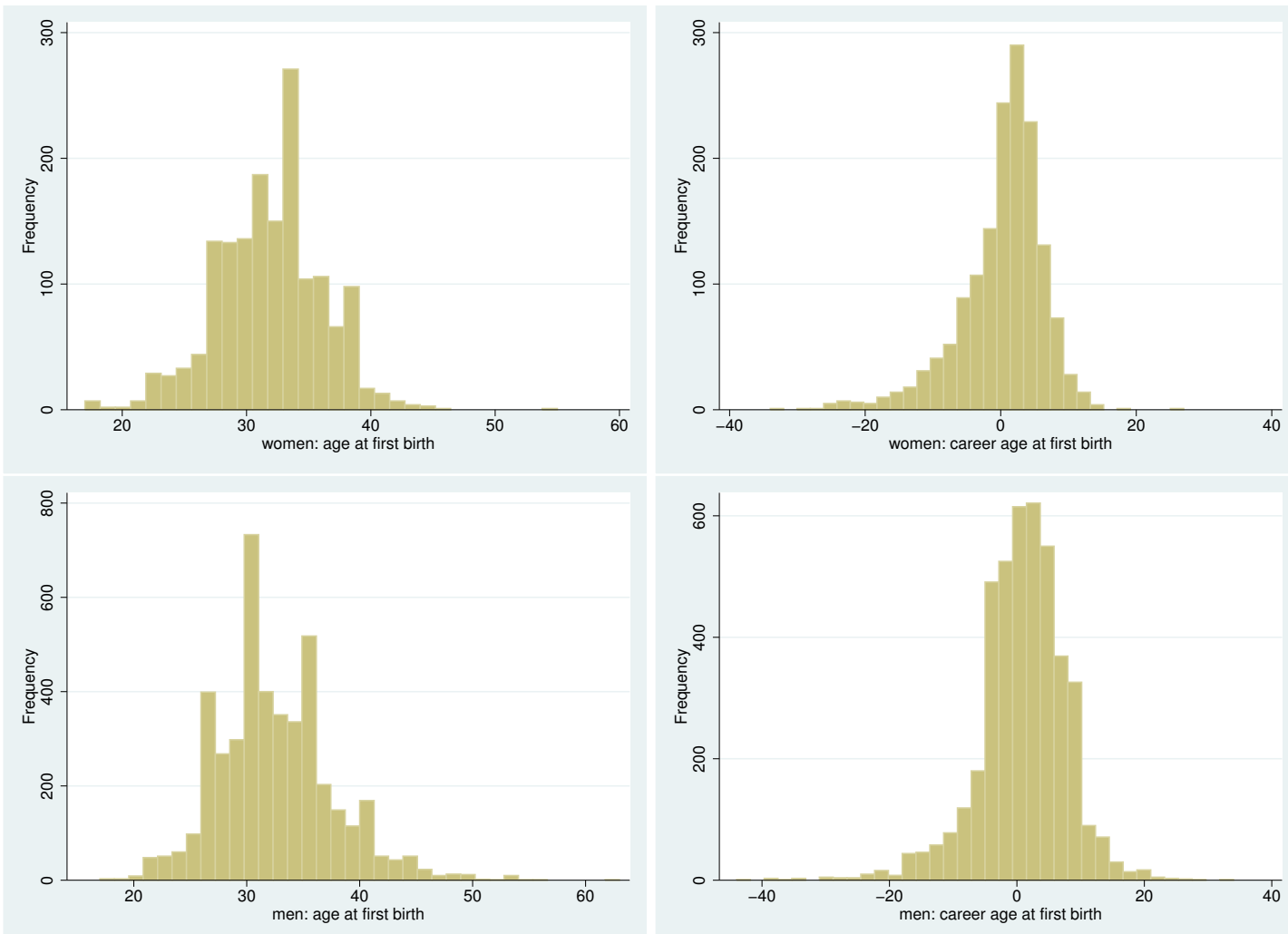

Figure 1: AGE AT FIRST BIRTH 
Table 4: Life-cycle Productivity (CW Index): Career Year Dummies vs. Fifth Order Polynomial Approximation.

\begin{tabular}{|c|c|c|c|c|c|c|c|}
\hline Variables & $\begin{array}{l}(1) \\
\text { all }\end{array}$ & $\begin{array}{c}\text { (2) } \\
\text { PhD-granting } \\
\text { institutions }\end{array}$ & $\begin{array}{l}\text { (3) } \\
\text { All }\end{array}$ & $\begin{array}{c}(4) \\
\text { Women }\end{array}$ & $\begin{array}{l}(5) \\
\text { Men }\end{array}$ & $\begin{array}{c}(6) \\
\text { Women in } \\
\text { PhD inst }\end{array}$ & $\begin{array}{c}(7) \\
\text { Men in } \\
\text { PhD inst }\end{array}$ \\
\hline Constant & $\begin{array}{l}-0.1980 \\
(0.1343)\end{array}$ & $\begin{array}{l}-0.1633 \\
(0.1733)\end{array}$ & $\begin{array}{c}2.4087 * * * \\
(0.0189)\end{array}$ & $\begin{array}{c}2.0152 * * * \\
(0.0466)\end{array}$ & $\begin{array}{c}2.3858 * * * \\
(0.0207)\end{array}$ & $\begin{array}{c}2.0434 * * * \\
(0.0598)\end{array}$ & $\begin{array}{c}2.5226 * * * \\
(0.0248)\end{array}$ \\
\hline Career & & & $\begin{array}{c}0.3585^{* * *} \\
(0.0055)\end{array}$ & $\begin{array}{c}0.3281 * * * \\
(0.0102)\end{array}$ & $\begin{array}{c}0.3665 * * * \\
(0.0064)\end{array}$ & $\begin{array}{c}0.3730 * * * \\
(0.0164)\end{array}$ & $\begin{array}{c}0.3810 * * * \\
(0.0096)\end{array}$ \\
\hline Career $^{2}$ & & & $\begin{array}{c}-0.0444 * * * \\
(0.0012)\end{array}$ & $\begin{array}{c}-0.0425^{* * *} \\
(0.0025)\end{array}$ & $\begin{array}{c}-0.0451 * * * \\
(0.0013)\end{array}$ & $\begin{array}{c}-0.0435 * * * \\
(0.0036)\end{array}$ & $\begin{array}{c}-0.0458 * * * \\
(0.0019)\end{array}$ \\
\hline Career $^{3}$ & & & $\begin{array}{c}2.26 \times 10^{-3 * * *} \\
\left(9.55 \times 10^{-5}\right)\end{array}$ & $\begin{array}{c}2.2 \times 10^{-3 * * *} \\
\left(2.15 \times 10^{-4}\right)\end{array}$ & $\begin{array}{c}2.29 \times 10^{-3 * * *} \\
\left(1.06 \times 10^{-4}\right)\end{array}$ & $\begin{array}{l}2.2 \times 10^{-3 * * *} \\
\left(3.04 \times 10^{-4}\right)\end{array}$ & $\begin{array}{c}2.29 \times 10^{-3 * * * *} \\
\left(1.43 \times 10^{-4}\right)\end{array}$ \\
\hline Career $^{4}$ & & & $\begin{array}{c}-5.12 \times 10^{-5 * * *} \\
\left(3.08 \times 10^{-6}\right)\end{array}$ & $\begin{array}{c}-4.91 \times 10^{-5 * * *} \\
\left(7.23 \times 10^{-6}\right)\end{array}$ & $\begin{array}{c}-5.18 \times 10^{-5 * * *} \\
\left(3.38 \times 10^{-6}\right)\end{array}$ & $\begin{array}{c}-4.84 \times 10^{-5 * * *} \\
\left(9.98 \times 10^{-6}\right)\end{array}$ & $\begin{array}{c}-5.14 \times 10^{-5 * * *} \\
\left(4.5 \times 10^{-6}\right)\end{array}$ \\
\hline Career $^{5}$ & & & $\begin{array}{c}4.24 \times 10^{-7 * * *} \\
\left(3.36 \times 10^{-8}\right)\end{array}$ & $\begin{array}{c}3.87 \times 10^{-7 * * *} \\
\left(8.14 \times 10^{-8}\right)\end{array}$ & $\begin{array}{c}4.29 \times 10^{-7 * * *} \\
\left(3.66 \times 10^{-8}\right)\end{array}$ & $\begin{array}{c}3.74 \times 10^{-7 * * *} \\
\left(1.11 \times 10^{-7}\right)\end{array}$ & $\begin{array}{c}4.24 \times 10^{-7 * * *} \\
\left(4.84 \times 10^{-8}\right)\end{array}$ \\
\hline PhD (1990-99) & $\begin{array}{c}-0.2379 * * * \\
(0.0165)\end{array}$ & $\begin{array}{c}-0.2277 * * * \\
(0.0179)\end{array}$ & $\begin{array}{c}-0.2442 * * * \\
(0.0164)\end{array}$ & $\begin{array}{c}-0.2872 * * * \\
(0.0422)\end{array}$ & $\begin{array}{c}-0.2353 * * * \\
(0.0178)\end{array}$ & $\begin{array}{c}-0.1215^{* *} \\
(0.0517)\end{array}$ & $\begin{array}{c}-0.2209 * * * \\
(0.0203)\end{array}$ \\
\hline PhD (2000+) & $\begin{array}{c}-0.3946 * * * \\
(0.0198)\end{array}$ & $\begin{array}{c}-0.3827 * * * \\
(0.0221)\end{array}$ & $\begin{array}{c}-0.3905 * * * \\
(0.0198)\end{array}$ & $\begin{array}{c}-0.3793 * * * \\
(0.0473)\end{array}$ & $\begin{array}{c}-0.3990 * * * \\
(0.0219)\end{array}$ & $\begin{array}{c}-0.1494 * * \\
(0.0622)\end{array}$ & $\begin{array}{c}-0.2779 * * * \\
(0.0274)\end{array}$ \\
\hline Female & $\begin{array}{c}-0.4990 * * * \\
(0.0167)\end{array}$ & $\begin{array}{c}-0.5314 * * * \\
(0.0190)\end{array}$ & $\begin{array}{c}-0.4992 * * * \\
(0.0167)\end{array}$ & & & & \\
\hline Tenured & & & & & & $\begin{array}{c}-0.4821 * * * \\
(0.0445)\end{array}$ & $\begin{array}{c}-0.1117 * * * \\
(0.0220)\end{array}$ \\
\hline Career dummies & yes & yes & no & no & no & no & no \\
\hline Log pseudolikelihood & -3002543.3 & -2349280.4 & -3008124 & -498610.12 & -2508472 & -293326.22 & -1672399.4 \\
\hline Observations & 153,425 & 111,962 & 153,425 & 36,951 & 116,474 & 17,999 & 66,327 \\
\hline
\end{tabular}

Notes: Poisson estimates without individual fixed effects; Robust standard errors are in parentheses;

$* * * p<0.01, * * p<0.05, * p<0.1$. 
exact effect is $\exp (\beta)-1$, which is smaller in absolute terms than the recorded values of $\beta$ for $\beta<0$. We use robust standard errors proposed by Wooldridge (1999) to allow for overdispersion. We include publications up to five career years prior to receipt of the $\mathrm{PhD}$ and center all careers on the year 0 in which the $\mathrm{PhD}$ was conferred.

To begin, we capture career age with the help of dummy variables for each career year. We control for gender and vintage effects by including two cohort dummy variables that indicate whether the $\mathrm{PhD}$ was obtained in the 1990s or later. The reference cohort thus consists of economists who received their doctorate before 1990. The estimates of this specification are reported in the first column of Table 4. The estimates show that gender matters: Female economists are less productive than male economists. Moreover, we find that cohort effects are indeed at work: The (historically) younger economists are, conditional on their career age, less productive than the older ones. We interpret these estimates of our vintage dummies to indicate changes in publication routines. As Conley, Crucini, Driskill, and Onder (2013) have pointed out, diminished productivity of recent cohorts can be attributed to increasing editorial delays, decreasing acceptance rates at journals, and a trend toward longer manuscripts. ${ }^{1}$ For the youngest cohort the estimated effect may, at least to some extent, also reflect a survivor bias; however, for the 1990s cohort a survivor bias can effectively be ruled out because individuals who have not undertaken economic research for many years are unlikely to have answered our survey. To check for any remaining survivor bias, we included in the next regression (Table 4, column (2)) only economists who had still stayed in academia (more precisely, were affiliated with $\mathrm{PhD}$-granting universities) when responding to the survey in 2012. To be sure, we cannot identify younger economists who will eventually quit and exclude them from our regressions. But the results do not suggest that our estimates are subject to an economically significant survivor bias.

We follow Goodwin and Sauer (1995) and Rauber and Ursprung (2008) to visualize the career cycles in research productivity and replaced the career year dummies with a career year polynomial of order 5. The regression results are reported in column (3) of Table 4. Since the decrease in the log-likelihood statistic is quite small compared with the first regression, little information is lost by using the career age polynomial instead of the career year dummies. We then ran the same regression separately for women and men; the results are reported in columns (4) and (5) of Table 4, respectively. The career patterns corresponding to the estimates reported in columns (1) and (3) are depicted in the left panel of Figure 2; the career patterns corresponding to the estimates in columns

\footnotetext{
${ }^{1}$ Hamermesh (2013) attributes the relative decline of the younger cohorts to a slowdown in technological progress in the economics profession. Whereas economists who went to graduate school in the 1960s and 1970 s benefited from the mathematization of economic analysis, the most recent batch of young economists can no longer overcome their disadvantage in experience by using new methods that are clearly superior to those used by previous generations of economists.
} 

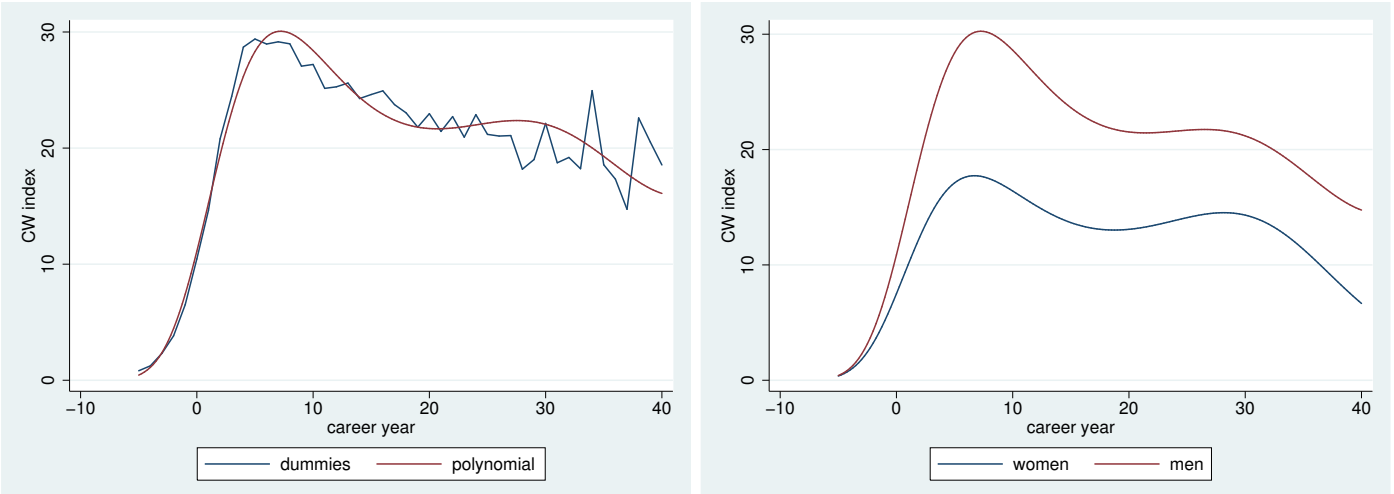

Figure 2: CAREER AGE CYCLES IN RESEARCH PRODUCTIVITY (CW INDEX) FOR COHORTS THAT OBTAINED THEIR PHDS BEFORE 1990. THE LEFT PANEL SHOWS THE PATTERNS FOR MEN.
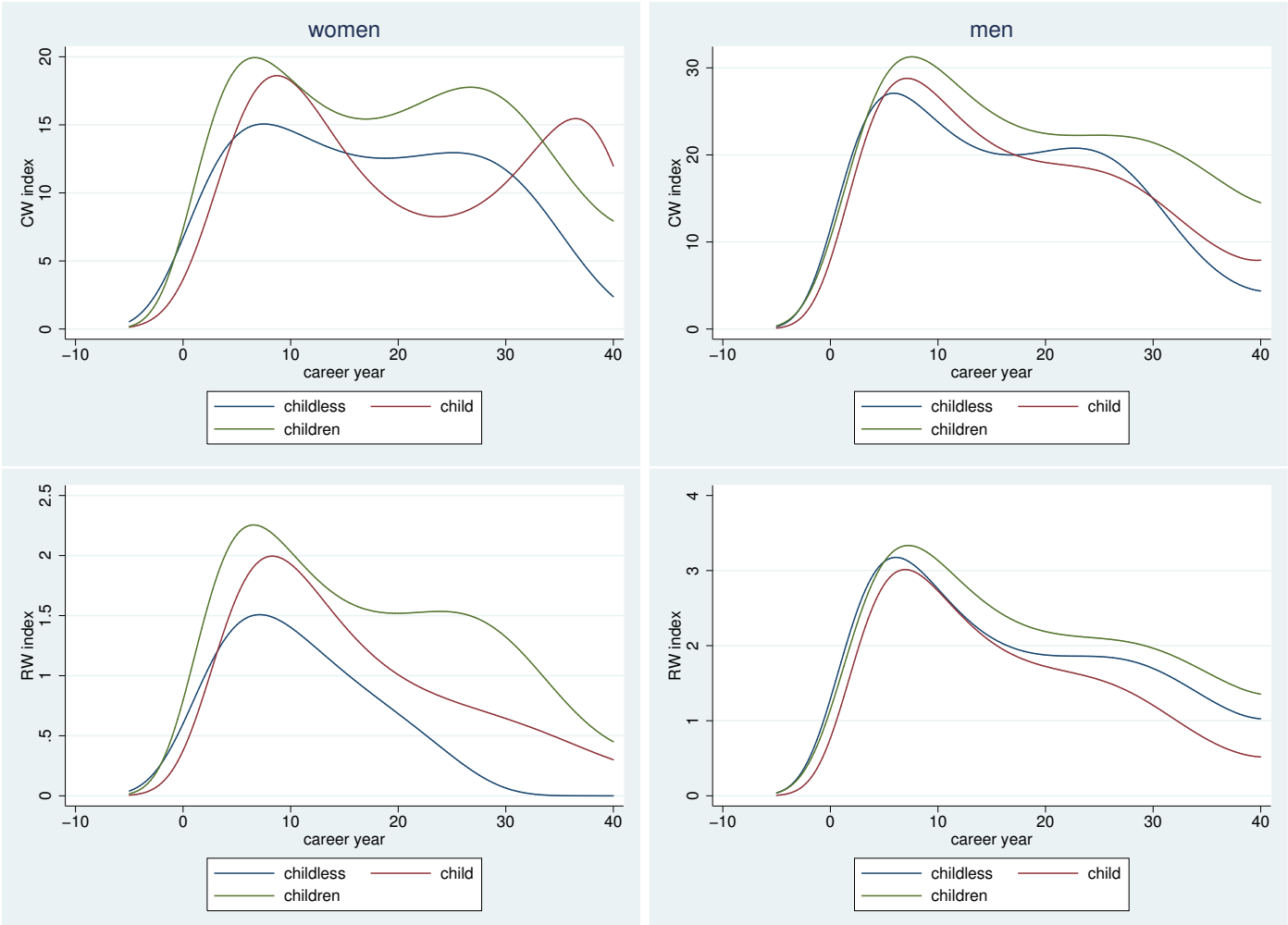

Figure 3: AVERAGE PATTERNS OF LIFECYCLE PRODUCTIVITY FOR WOMEN AND MEN WITH 0, 1, AND 2 OR MORE CHILDREN. THE FIGURES IN THE TOP PANELS ARE BASED ON THE REGRESSION OUTPUT REPORTED IN TABLE C.1. 
(4) and (5) are shown in the right panel. The hump-shaped career patterns in research productivity are perfectly compatible with the predictions of human capital theory and are in line with the patterns previously identified by Goodwin and Sauer (1995) for 140 economists working at 7 top American economics departments and by Rauber and Ursprung (2008) for an encompassing census of economists working at Austrian, German, and Swiss universities. ${ }^{2}$ Research productivity peaks 7 to 8 years after receiving the $\mathrm{PhD}$, remains pretty flat in the mid-career period (i.e., during career years 15-25), and then begins to drop until retirement. The right panel of Figure 2 indicates that men are, on average, more productive than women, but otherwise the shape of the productivity patterns of male and female economists is quite similar. ${ }^{3}$

Columns (6) and (7) of Table 4 restrict the sample to male and female economists affiliated with $\mathrm{PhD}$-granting institutions and include a tenure dummy variable, which is 1 for tenured economists and 0 otherwise. The estimated coefficient of the tenure dummy is indicative of a tenure kink in research productivity. Female economists appear to suffer a larger tenure-induced productivity drop than their male peers. It is reasonable that the tenure kink of females is larger because women may well shift childbearing to their posttenure career and therefore become less productive after they are tenured. We explore this hypothesis further in the next section in which we explore the research productivity of parents.

\subsection{Career cycles of parents}

Since the observed family structure may reveal some of the respondents' ex ante heterogeneity, we estimated career cycles in research productivity for economists with no children, one child, and two or more children. The respective regressions include only those individuals who are not likely to have another child. ${ }^{4}$ Figure 3 depicts the career patterns in research productivity for men and women separately. (The estimates are relegated to Tables C.1 and C.2.)

Figure 3 indicates that, contrary to conventional wisdom, economists with children are not less productive than their childless colleagues. This statement also applies to women. The depicted career life cycles in research productivity as measured by the RW index suggest that economists with two or more children are, on average, more productive than their peers with only one child or no children. Using the CW index of research productivity does, however, not yield a clear correlation between productivity and fertility.

\footnotetext{
${ }^{2}$ In a recent study, Conley, Crucini, Driskill, and Onder (2013) use a much larger sample of U.S. and Canadian academic economists than Goodwin and Sauer (1995) and find very similar career patterns.

${ }^{3}$ Career cycles estimated using fixed effects have similar shapes. In this section, we prefer to show the estimates without fixed effects because in our figures we want to compare the career cycles of male and female economists, which is possible only if a common constant term (intercept) is identified.

${ }^{4}$ To be more specific, we only included people in our sample who received their PhD before 1990.
} 
Table 5: Age of CHILDREN (CW INDEX)

\begin{tabular}{lcccc}
\hline \hline & $(1)$ & $(2)$ & $(3)$ & $(4)$ \\
Variables & Women & Men & Mothers & Fathers \\
\hline children & $-0.1766^{* * *}$ & $-0.0497^{* *}$ & $-0.1912^{* * *}$ & $-0.0538^{* *}$ \\
& $(0.0533)$ & $(0.0232)$ & $(0.0555)$ & $(0.0235)$ \\
teenager & 0.0161 & 0.0175 & 0.0041 & 0.0253 \\
& $(0.0735)$ & $(0.0328)$ & $(0.0776)$ & $(0.0325)$ \\
twen_plus & -0.2686 & -0.0297 & -0.1526 & 0.0187 \\
& $(0.1657)$ & $(0.0878)$ & $(0.1716)$ & $(0.0841)$ \\
tenured & $-0.3918 * * *$ & $-0.2457^{* * *}$ & $-0.4074 * * *$ & $-0.2484 * * *$ \\
& $(0.0646)$ & $(0.0324)$ & $(0.0764)$ & $(0.0369)$ \\
\hline Log pseudolikelihood & -227724.03 & -1163238.5 & -172956.48 & -906351.32 \\
Observations & 20,399 & 76,529 & 14,710 & 59,243 \\
Individuals & 1,107 & 3,469 & 786 & 2,627 \\
\hline \hline
\end{tabular}

Notes: Poisson estimates with individual fixed effects; career year controls (fifth-order polynomial) included; Robust standard errors are in parentheses; $* * * p<0.01, * * p<0.05, * p<0.1$.

The productivity cycles of fathers of one child and of childless men intersect and are almost congruent. On the other hand, the productivity cycle of mothers of one child shows a marked decrease after the early career peak and a surprising recovery toward the end of the career. Whereas the bimodal shape of the productivity cycle of mothers of at least two children is indicative of a motherhood effect, the trough of the productivity cycle of mothers of one child appears to last too long to be attributable to motherhood. The picture is more intuitive if the RW index of research productivity is used. Mothers of at least two children are, on average, more productive than mothers of only one child, and mothers in general are more productive than childless women. Fathers of at least two children are also more productive than fathers of one child and childless men. Toward the end of their careers, however, childless men appear to be somewhat more productive than fathers of one child. The overall picture is thus consistent with the study by Joecks, Pull, and Backes-Gellner (2013) that identifies a positive correlation between parenthood and productivity among economists in the German-language countries.

We introduce two sets of dummy variables indicating the presence of children to further investigate the association of parenthood with research productivity. The first set consists of four dummy variables: pre_children (1 if the respondent has no children), children ( 1 if the respondent has at least one child 12 years of age or younger), teenager ( 1 if a respondent's youngest child is between 13 and 19 years of age), and twen_plus ( 1 if a respondent's children are all 20 years of age or older). Table 5 reports the results when the variables children, teenager, and twen_plus are included in our career cycle 
Table 6: Number of CHILDREN (CW INDEX)

\begin{tabular}{lcccc}
\hline \hline & $(1)$ & $(2)$ & $(3)$ & $(4)$ \\
& Women & Men & Mothers & Fathers \\
\hline 1_child & -0.0409 & -0.0117 & -0.1003 & -0.0172 \\
& $(0.0697)$ & $(0.0400)$ & $(0.0750)$ & $(0.0450)$ \\
2_children & $-0.1640 *$ & -0.0005 & $-0.2503 * *$ & -0.0076 \\
& $(0.0883)$ & $(0.0439)$ & $(0.0987)$ & $(0.0496)$ \\
3_children & $-0.3006 * *$ & 0.0168 & $-0.3972 * * *$ & -0.0078 \\
& $(0.1273)$ & $(0.0628)$ & $(0.1368)$ & $(0.0717)$ \\
all_13_plus & -0.0909 & 0.0374 & -0.1324 & 0.0486 \\
& $(0.0994)$ & $(0.0509)$ & $(0.1078)$ & $(0.0530)$ \\
tenured & $-0.3930 * * *$ & $-0.2475 * * *$ & $-0.4058^{* * *}$ & $-0.2512^{* * *}$ \\
& $(0.0650)$ & $(0.0321)$ & $(0.0767)$ & $(0.0366)$ \\
\hline Log pseudolikelihood & -227909.79 & -1163430.5 & -172981.61 & -906536.59 \\
Observations & 20,399 & 76,529 & 14,710 & 59,243 \\
Individuals & 1,107 & 3,469 & 786 & 2,627 \\
\hline \hline
\end{tabular}

Notes: Poisson estimates with individual fixed effects; career year controls (fifth-order polynomial) included; Robust standard errors are in parentheses; $* * * p<0.01, * * p<0.05, * p<0.1$.

estimates of productivity. The reference category is the group of respondents who have no children. The Poisson estimates for men and women now include individual fixed effects. The results indicate that having preteen children is associated with lower research productivity for both mothers and fathers. Not surprisingly, the reduction in productivity is larger for mothers than for fathers: Mothers of preteens have an average loss of productivity of about $17.4 \%(=\exp (-0.1912)-1)$, whereas the fathers lose a mere $5 \%$ in productivity. Nevertheless, it is interesting to note that parenthood is also associated with lower productivity for men. We refer here to the estimates for the sample of respondents who actually do have children (columns (3) and (4)). The estimated values of the coefficients of the variable children are nearly the same size for the whole sample (columns (1) and (2)). The estimated coefficients of the teenager and twen_plus dummy variables are not statistically different from zero. To be sure, omitted-variable bias matters for these estimates, but only a few background variables are available. Since we know at least when people obtained tenure, we include a tenure dummy. The coefficient has the expected negative sign and is statistically different from zero.

Up to this point, we have used a set of variables that indicate only parenthood but do not differentiate between the number of children. Table 6 reports the estimates of career cycle regressions that include a set of five dummy variables referring to the number of preteen children: no_child, 1_child (1 if the first child is younger than 13 years and 
another child is not yet born); 2_children (1 if the second child is younger than 13 years and another child is not yet born); 3_children (1 if the third child is under 13 years and another child is not yet born); and all_13_plus (1 if the youngest child is at least 13 years of age). Again focusing on the regression results based on the restricted sample of economists who are actually parents (columns (3) and (4)), we see that for mothers an increasing number of preteen children is associated with an increasing loss in productivity: One child is associated with a productivity loss of 9.5\% $(=\exp (-0.1003)-1)$, two children with a loss of $22 \%(=\exp (-0.2503)-1)$, and three children with a loss of $33 \%$ $(=\exp (-0.3972)-1)$. For mothers, the marginal cost of children thus appears to be constant in the number of children. For men, we do not find coefficients that are either economically or statistically significantly different from zero.

Table 7 presents estimates of the effect of twins on research productivity. If twin births were exogenous, this would be our best estimate in terms of cleanly identifying the causal effect of parenthood on the productivity of highly skilled labor.

A total of 204 survey respondents (56 women and 148 men) indicated that two of their children were born in the same year. To be sure, we cannot rule out that this way of identifying twin births may include "Irish twin" births. Since we observe, however, much fewer twin births than one could have expected, ${ }^{5}$ we feel confident that the potential "Irish twin" bias is not likely to be a serious problem. The relatively small number of twin births in our sample might be due to several reasons. First, since the chances of having twins increases with the number of preceding births, our first-time parents are less likely to have twins. Second, the older the mother, the higher are the chances of having fraternal twins - and the mothers in our sample are, of course, substantially older (on average) when they give birth for the first time than mothers in general. Finally, it is well understood that the use of fertility drugs and assisted reproductive technology to help women conceive increase the probability of conceiving twins. One might thus speculate that the low incidence of twin births in our sample is due to highly educated professionals being less likely to undergo fertility treatment because they are better able to accept childlessness than people who find less satisfaction in their professional lives.

The last argument gives immediately rise to a second caveat. Since twin births are more likely after a woman has undergone fertility treatments, twin births are not perfectly exogenous events. Indeed, the 42 mothers whose first pregnancy resulted in the birth of twins were, on average, 34.8 years old when the twins were born and the 94 fathers whose first children were twins were, on average, 35.5 years old. These numbers are considerably higher than the corresponding overall means of 31.9 and 32.5 years of age at

\footnotetext{
${ }^{5}$ Martin, Hamilton, and Osterman (2012) report that the twin birth rate rose 76 percent between 1980 and 2009, from 18.9 to 33.3 per 1,000 births. Dividing the 204 twin births in our data set by the more than 12,000 births to the respondents to our survey, we obtain a rate at the lower end of that range, which would indicate that the fertility treatments that increased the general twin rate are negligible in our sample.
} 
Table 7: THE EFFECT OF TWINS

\begin{tabular}{lcccc}
\hline \hline & $(1)$ & $(2)$ & $(3)$ & $(4)$ \\
Variable & Women & Men & Mothers & Fathers \\
\hline Twins & -0.1106 & $0.4322^{* * *}$ & -0.1673 & $0.4218^{* *}$ \\
& $(0.2810)$ & $(0.1665)$ & $(0.2761)$ & $(0.1675)$ \\
\hline Log pseudolikelihood & -227946.21 & -1162521 & -173016.94 & -905617.61 \\
Observations & 20,399 & 76,529 & 14,710 & 59,243 \\
Individuals & 1,107 & 3,469 & 786 & 2,627 \\
\hline \hline
\end{tabular}

Notes: Poisson estimates with individual fixed effects; career year controls (fifth-order polynomial) included; Robust standard errors are in parentheses; *** $p<0.01, * * p<0.05, * p<0.1$.

the first birth reported in Table 2. As argued above, some of this difference may be due to the fact that older women are more likely to have twin births. But the difference may also suggest that at least some of these twin births may have resulted from fertility treatments. But even acknowledging this kind of endogeneity, it is not clear whether an especially strong wish for children resulting in fertility treatments is systematically associated with productivity: on the one hand, less productive female scientist may want to substitute motherhood for lacking academic success, on the other hand, highly productive female scientists may have a greater demand for children because they are better able to cope with the additional burden of motherhood. Our estimating strategy would only yield an underestimate of the motherhood effect if less productive female scientists are more prone to make use of fertility treatments than productive ones. This is so because, as we will show below, the motherhood effect is probably larger for highly productive scientist than for more ordinary scientists.

Our dummy variable assumes the value of 1 in the year in which two babies were born and in the following 12 years; in all other years the dummy is set equal to 0 . Since we observe only four triplets (i.e., three births in one year) in our sample, we were not able to estimate a triplet effect. We did not include the triplets in the twin-effect regression reported in Table 7. We included all variables from Table 6 in the regressions reported in Table 7 as control variables. The estimates of all of these variables were not affected by the inclusion of the twin variable.

For women and mothers, the estimates of the twin effect are somewhat smaller than the estimates of the children effect reported in Table 5 and the two-child effect reported in Table 6. Since the children effect cannot be readily compared with the effect of exactly two children, the rather small difference is easily explained. More interesting is that the twin effect amounts to only about two-thirds of the two-child effect. We conjecture that this can be accounted for by economies of scale. Driving the son to his ballet lesson 
and the daughter to her soccer training is simply more disruptive than driving the twins together to their violin teacher. The fact that the twin effect ultimately is statistically insignificant is not worrisome; this is simply a consequence of the small number of twin births in our sample.

The twin effect on men's or fathers' labor productivity is positive, statistically significant, and surprisingly large. Fathers become $52.5 \%(=\exp (0.4218)-1)$ more productive after the birth of twins, whereas children per se have, if anything, a negative effect on their productivity. It appears that the surprise shock associated with the birth of twins affects fathers much more than mothers, who by choosing to become a mother, have already prepared themselves for substantial changes in their professional life, whereas the father of twins may have allowed himself to be lulled into a false sense of remaining largely unaffected by fatherhood.

In any event, the rather clean estimates of the twin effects reinforce our confidence that our previous estimates of parenthood effects are not likely to be unduly corrupted by reverse causality links. The size of the estimated twin effect, in particular, lends support to our finding that the marginal effect of a woman's first child is surprisingly small. It therefore seems natural to ask whether the small size of this effect is representative. After the birth of their first child, mothers are obviously less flexible in the use of their time. On the other hand, they may better use the time that is left. Different groups of women may be better or less able to deal with the burden of motherhood, which generates sufficient variation for the effect to become statistically insignificant. The finding that the marginal effect of a woman's first child is economically but not statistically significant is our main motivation for the analysis performed in the next section.

\section{Semiparametric difference-in-differences estimation}

\subsection{Method}

The descriptive statistics in the previous section suggest that researchers with children differ greatly from researchers without children. We therefore extensively used regressions that include individual fixed effects to remove any estimation bias related to time-invariant unobserved heterogeneity. In this section, we use a difference-in-differences estimation, a special case of fixed effects regression, in our attempt to identify the effect of pregnancy and parenthood on research productivity. Our questionnaire survey elicited the pretreatment values of a set of covariates upon which we condition.

Our identification strategy is to reduce our panel to two observation periods: A pretreatment period and a posttreatment period. All individuals in our sample are of an age when many of their peers become parents. All individuals have no children before treat- 
ment. The treated are those who become parents, whereas the individuals in the control group had no children when the survey was taken. We choose research productivity in the three years before treatment as the pretreatment productivity and the research productivity in the three years after treatment as the posttreatment productivity.

A standard difference-in-differences test would compare the change in productivity of the treated between the pretreatment and the posttreatment period with the corresponding change for the control group. These standard difference-in-differences tests are based on the assumption that the average outcome for both the treated and the control groups would have followed parallel paths over time in the absence of treatment (common trend assumption). The common trend assumption is reasonable for large randomly-formed treatment and control group. Unfortunately, we cannot expect this assumption to be correct in our case because researchers with and without children (the treatment and control groups) differ along many dimensions and some of these differences also co-determine fertility - that is, the assignment to the two groups is not random but rather endogenous. If, however, the researchers' characteristics differ between the treated and the control groups, the common trend assumption is very likely to be violated and the pretreatment differences can be expected to be related to the dynamics of the outcome variable after treatment. As we have seen, at least according to one output measure, prospective parents are, on average, more productive before they have children than their peers who will never have children (the difference is statistically not significant, but still exists). If, however, a person was more productive before treatment, then it is likely that he or she will also be more productive afterward. Moreover, it may also be more likely that this person will become a parent because efficient people may be better able to cope with the ensuing double burden of work and parenting.

Because treatment is endogenous, the treatment effect needs to be conditioned on the determinants that are likely to influence the variable to be explained (research productivity) and the probability of being treated (fertility). Determinants that correlate with research productivity and fertility are, for example, the age of the participants; their pretreatment research output; academic/cultural background; marital status; the educational level of their spouse; and the availability of child care.

The estimator proposed by Abadie (2005) accounts for this heterogeneity in pretreatment circumstances by combining propensity score weighting with difference-indifferences estimation. In a first step, the set of confounders is used to estimate propensity scores by means of power series estimation. Power series estimation is a linear estimation method that includes higher exponential terms of the confounders up to order $K$, where $K$ is chosen through cross-validation (see chapter 15 of Li and Racine, 2006). Typically, propensity scores are estimated using binary choice models such as logit or probit models. Propensity score weighting is easy to implement for binary choice models, but remains 
asymptotically inefficient compared with strict matching techniques. Hirano, Imbens, and Ridder (2003) show, however, that in finite samples inverse propensity score weighting yields efficient estimators when the propensity scores are derived semiparametrically.

In the second step, the propensity scores are used to measure the effect of treatment on the treated, where the outcome of interest is not measured in levels but in differences. This estimator has been used previously in the economics of science literature by Azoulay, Graff Zivin, and Manso (2011), who take advantage of the fact that conditional differencein-differences measures the "treatment-of-the-treated" effect and compare it with average treatment effects.

In applying the Abadie estimator, we do not argue that this strategy allows us to take all endogeneity into account. Just as with matching and propensity score weighting estimators in general, selection is only on "observables." As argued by, among others, Angrist and Pischke (2008), this makes matching and propensity score weighting estimators basically equivalent in terms of causal interpretation to conventional regression estimators. These estimators make an assumption referred to as conditional independence assumption. If this assumption is not violated, then there is no omitted variable bias. This assumption is plausible if the set of variables that we condition upon in the computation of the propensity scores (confounders) satisfies the following properties: First, all variables that may influence an individual's decision whether to select into the treatment group (whether to have children or not) and that may at the same time be correlated with the output trend over the period of interest (the research productivity as a parent) are included. We paid attention to this condition in tailoring the questionnaire (see Appendix A). Second, these variables need to be measured before selection takes place. We know the research productivity before an economist decides to become a parent. Even if our estimator does not solve all problems related to endogeneity, we are still confident that the estimates provide a relatively accurate impression of the overall effect of pregnancy and parenthood on research productivity.

In addition to accounting for endogeneity, the Abadie estimator has another feature that is perhaps even more important in our context: It allows us to compute conditional treatment effects, that is, when we estimate the treatment effects in the second step of the procedure, we can select subsets of the variables used in the first step to compute the propensity scores and then compute treatment effects that are conditional on these variables. For example, in estimating the propensity score we include a dummy variable indicating whether a person is married or lives in a marriage-like (committed) relationship because being married or living in a committed relationship (i) is likely to be related to whether someone will have a child or not and (ii) may also be correlated with research productivity. Inclusion of this dummy variable ultimately yields two estimates of treatment effects: one for individuals who are married or in a relationship and one for those 
who are not.

\subsection{Data treatment analysis}

Individuals in the control group are respondents with no children. We use data from the year 2007 for this control group. The treatment group consists of men and women who became parents for the first time between 2004 and 2007. We restrict our sample to men born between the years 1959 and 1981 and women born between the years 1965 and 1981. The youngest individuals in our sample are in their mid-20s, at the beginning of their academic careers. The oldest women are 42 years of age, the oldest men are 48 years of age. It does not seem practical to examine the effect of becoming a parent for older people. The resulting sample consists of 2,433 economists. This includes 496 childless women, 288 mothers, 978 childless men, and 671 fathers.

Descriptive statistics are provided in Appendix D. Concerns about the support of the age distribution in the treatment and control groups prove to be unfounded. All other variables used to compute the propensity scores are dummy variables. The descriptive statistics for these confounders are listed in Table D.1. It transpires, for example, that parents are more likely to be top-quartile researchers and to have more-educated spouses than economists with no children.

In the following, we compare changes in research output between the three years before and the three years after treatment for the treated group, and before and after 2007 for the controls. Output is measured by the cumulative RW indices over the three years before and after the cutoff year. The outcome is thus defined as $Y_{i 1}-Y_{i 0}$, where $Y_{i 1}$ is either the sum of the RW values of a parent over the first three years of parenthood or the sum of the RW values of a childless economist over the years 2008 to 2010. $Y_{i 0}$ is either the sum of the RW values over the three years before parenthood or the sum of the RW values of a childless economist over the years 2004 to 2006.

\subsection{Results}

To predict parenthood, we use various variables, all of which relate to the time before treatment - that is, before the first child was born. ${ }^{6}$ The first set of variables measures academic success: These variables indicate whether economists have earned a $\mathrm{PhD}$, received tenure, and were in the top quartile according to their cumulative pre-childbirth research output. We use the cumulative research output because the decision to have children depends on the entire oeuvre achieved by that time rather than on current research productivity. After all, the wish to have children may well derive from expected promotion, which, in academia, depends mainly on life-time research output.

\footnotetext{
${ }^{6} \mathrm{We}$ believe that the time before childbirth is a sufficient proxy for the time before conception.
} 
The second set of variables refers to the family environment: These variables (i) indicate whether the economists were married, (ii) whether day care services were available, and (iii) identify the education level of the spouse. We also include demographic variables: a dummy indicating the continent on which the $\mathrm{PhD}$ degree was earned, ${ }^{7}$ the economists' age, and higher-order exponential terms of age up to order $K$. Since using higher powers of indicators makes sense only for metric variables, the analysis is substantially simplified by the fact that all but the age variable are dummy variables. We use cross-validation to select the order $K$ of the age polynomial. For women, the plots suggest that the integrated mean square error is minimized for $K=2$, and for men it is minimized for $K=4$. Since we compute the propensity scores using a linear estimator with higher-order exponential terms, propensity scores outside the $(0,1)$ range may result. Dropping observations outside the $(0,1)$ range, we are left with 1,459 out of 1,649 men and with 665 out of 784 women for our second-step analysis.

Table 8 shows how these variables relate to subsequent parenthood (i.e., to being assigned to the treatment or the control group in the second-step regressions). When interpreting these estimates, note that the standard errors reported in Table 8 are subject to heteroskedasticity. This is not important for the second-stage estimates because we use the results documented in Table 8 only to compute propensity scores. Women who have already obtained their $\mathrm{PhD}$ degree are more likely to have children than female PhD students, but neither research output nor achieving tenure appear to influence the decision of female economists to become mothers. For men, none of these variables measuring academic success contribute to explaining fatherhood. Family environment variables are more important for the fertility decision. Both men and women are more likely to have children if they are married or in a committed relationship, and they are less likely to have children if they know that day care services are not available. Moreover, female academics are not less likely to have children if their spouse has an advanced university education.

With regard to the demographic variables, none of the four women in our sample who received their $\mathrm{PhD}$ degree in Africa has children. Asian men (or more precisely, men who received their graduate education in Asia) are somewhat more likely, and European men are somewhat less likely to father a child than other men. The age polynomial shows again that the fertility of women peaks at the age of 33 . For men, the estimates in Table 8 indicate a local fertility maximum at the age of 35.8

\footnotetext{
${ }^{7}$ The continent on which the $\mathrm{PhD}$ was earned is very likely to be a pre-childbirth (pretreatment) variable because only very few economists in our sample had their first child before they entered graduate school, and only some of the few individuals who had have children before entering graduate school moved to another continent to receive their graduate education.

${ }^{8}$ These numbers are somewhat higher than the average age at first birth reported in Table 1 and Figure 1. One reason for this difference is that in this section we deal with younger cohorts who have their first children later on average than earlier cohorts. Sampling may play also a role. Since individuals who had their first
} 
Table 8: Power Series Estimates of the Determinants of Parenthood

\begin{tabular}{|c|c|c|}
\hline & (1) & $(2)$ \\
\hline Variables & Women & Men \\
\hline \multirow[t]{2}{*}{ Constant } & $-5.5856 * * *$ & $36.8653 * *$ \\
\hline & $(0.8236)$ & $(15.1737)$ \\
\hline \multirow[t]{2}{*}{$\mathrm{PhD}$} & $0.1018 * * *$ & 0.0081 \\
\hline & $(0.0399)$ & $(0.0289)$ \\
\hline \multirow[t]{2}{*}{ Tenured } & 0.0489 & -0.0177 \\
\hline & $(0.0444)$ & $(0.0300)$ \\
\hline Pre-birth output & 0.0338 & 0.0284 \\
\hline (top-quartile CW) & $(0.0372)$ & $(0.0269)$ \\
\hline \multirow[t]{2}{*}{ Married } & $0.2294 * * *$ & $0.3210^{* * *}$ \\
\hline & $(0.0552)$ & $(0.0402)$ \\
\hline \multirow[t]{2}{*}{ Spouse high school } & 0.1324 & $0.1642 * * *$ \\
\hline & $(0.0818)$ & $(0.0630)$ \\
\hline \multirow[t]{2}{*}{ Spouse college } & $0.1250 *$ & $0.1561 * * *$ \\
\hline & $(0.0720)$ & $(0.0436)$ \\
\hline \multirow[t]{2}{*}{ Spouse master's degree } & $0.2123 * * *$ & $0.1791 * * *$ \\
\hline & $(0.0623)$ & $(0.0400)$ \\
\hline \multirow[t]{2}{*}{ Spouse PhD } & $0.1874 * * *$ & $0.1560 * * *$ \\
\hline & $(0.0588)$ & $(0.0454)$ \\
\hline \multirow[t]{2}{*}{ Day care available } & 0.0219 & 0.0561 \\
\hline & $(0.0450)$ & $(0.0353)$ \\
\hline \multirow[t]{2}{*}{ Day care unavailable } & $-0.2390 * * *$ & $-0.2485^{* * *} *$ \\
\hline & $(0.0445)$ & $(0.0369)$ \\
\hline \multirow[t]{2}{*}{ PhD Africa } & $-0.2517 * * *$ & 0.1437 \\
\hline & $(0.0868)$ & $(0.1188)$ \\
\hline \multirow[t]{2}{*}{ PhD Asia } & -0.0916 & $0.0960 *$ \\
\hline & $(0.0992)$ & $(0.0503)$ \\
\hline \multirow[t]{2}{*}{ PhD Europe } & 0.0063 & $-0.0495 * *$ \\
\hline & $(0.0313)$ & $(0.0226)$ \\
\hline \multirow[t]{2}{*}{ PhD Latin America } & -0.0002 & -0.0219 \\
\hline & $(0.2100)$ & $(0.0866)$ \\
\hline \multirow[t]{2}{*}{ PhD Oceania } & -0.0460 & -0.0248 \\
\hline & $(0.1207)$ & $(0.0700)$ \\
\hline \multirow[t]{2}{*}{ Age/100 } & $34.3266^{* * *}$ & $-436.6983 * *$ \\
\hline & (4.9991) & $(173.2997)$ \\
\hline \multirow[t]{2}{*}{$(\text { Age } / 100)^{2}$} & $-51.5218 * * *$ & $1905.911 * * *$ \\
\hline & $(7.3982)$ & $(733.4921)$ \\
\hline \multirow[t]{2}{*}{$(\text { Age } / 100)^{3}$} & & $-3618.629 * * *$ \\
\hline & & (1363.403) \\
\hline \multirow[t]{2}{*}{$(\text { Age/100) })^{4}$} & & $2520.652 * * *$ \\
\hline & & (939.1079) \\
\hline$R^{2}$ & 0.3571 & 0.3395 \\
\hline Observations & 784 & 1,649 \\
\hline
\end{tabular}

Notes: Robust standard errors are in parentheses; $* * * p<0.01, * * p<0.05$, $* p<0.1$. 
Then, we compute the conditional and unconditional treatment effects. The results for women are shown in Table 9 and those for men in Table 10. We focus again on our benchmark measure of research output, the $\mathrm{CW}$ index. Corresponding estimates based on the alternative three research productivity measures are provided in Appendix E. The coefficients reported in Tables 9 and 10 estimate the effect of parenthood on the cumulated absolute change in research productivity over the three years following childbirth. To provide a basis of comparison, note that women and men typically have their first child in the first or second career year after receiving their $\mathrm{PhD}$ (see Figure 1). The annual research output at that stage of their careers amounts to about 15 points for women and 20 points for men (see Figure 3).

The coefficients reported in the first line of Tables 9 and 10 are, technically speaking, estimates of the constant terms of the regression equations: They measure the effect of parenthood on research output for all those academics who do not share the characteristics indicated by the covariates in the respective column. To begin with, no covariates are included in column (1). The coefficient of the constant variable thus provides our estimate of the unconditional treatment effect of the treated. The estimate is negative, relatively small, and statistically not significant, implying that pregnancy, childbearing, and motherhood have no large effect on the mother's research productivity in the first three years after the birth of her first child. This result is in line with our previous estimate of the effect of a first child on research productivity (see column (3) in Table 6). There, we obtained a statistically insignificant point estimate suggesting a productivity loss of about $10 \%$. Now we obtain a similar result with a different estimation method: The estimated reduction in research output of about 4 points roughly corresponds to a $10 \%$ reduction in the average three-year output of 45 points. Propensity score weighting thus does not appear to greatly affect the size of our earlier estimate. ${ }^{9}$ However, the rather large standard errors suggest a great deal of variation in the motherhood effect among women with different backgrounds. We therefore now turn to identifying conditional treatment effects to clarify which women are most likely to suffer a drop in research output and which are better able to manage the burden of motherhood. For men, the unconditional effect is also statistically insignificant, but it is sizable and has a positive sign.

child before 2004 were dropped, only men without children remain in the sample. Conditioning on not yet having a child, older men may be more likely to become fathers, which may raise the age at first fatherhood. Figure D.1 visualizes the age distributions for men and women in the treatment and control groups.

${ }^{9}$ Tables E.15 and E.17 show that the unconditional effect of motherhood remains statistically insignificant but changes its sign when we use the indices RF and CF, which date research by the year of publication. The positive sign is likely due to articles that were written before motherhood but appeared only in the three years after the first child's birth. Since working paper versions are not available for many publications in our dataset, the negative estimates obtained with the $\mathrm{CW}$ index are probably downward biased, implying that the estimates might become statistically significant if we were better able to pinpoint the time when the research was actually undertaken. 
Table 9: Semiparametric Difference-In-Difference Estimates of the EFFeCt of Parenthood for Women (CW InDEX)

\begin{tabular}{|c|c|c|c|c|c|c|c|c|c|c|c|}
\hline Variables & $(1)$ & $(2)$ & (3) & (4) & $(5)$ & (6) & (7) & (8) & (9) & (10) & $(11)$ \\
\hline \multirow[t]{2}{*}{ Constant } & -3.8664 & $-17.2834 * * *$ & $-18.5424 * *$ & $-12.8064 *$ & -2.8312 & -2.8030 & 1.1520 & $-12.9511 * *$ & $-10.8169 *$ & 3.5120 & -27.2866 \\
\hline & $(4.0336)$ & $(6.4424)$ & $(7.3045)$ & $(6.5502)$ & (4.1599) & $(4.5877)$ & $(3.4092)$ & $(6.4372)$ & $(6.5251)$ & $(12.8201)$ & (18.7796) \\
\hline \multirow[t]{2}{*}{ Married } & & $14.4088^{*}$ & 11.9315 & & & & & & & & 14.4498 \\
\hline & & $(7.9230)$ & $(9.4154)$ & & & & & & & & $(9.1942)$ \\
\hline \multirow[t]{2}{*}{ Spouse college } & & & 3.8784 & & & & & & & & -0.0188 \\
\hline & & & $(10.1714)$ & & & & & & & & $(10.2590)$ \\
\hline \multirow[t]{2}{*}{ Day care available } & & & & 10.1861 & & & & & & & 10.1211 \\
\hline & & & & $(8.6831)$ & & & & & & & $(8.3872)$ \\
\hline \multirow[t]{2}{*}{ Day care unavailable } & & & & 13.9458 & & & & & & & 12.6897 \\
\hline & & & & $(12.0072)$ & & & & & & & $(12.5087)$ \\
\hline \multirow[t]{2}{*}{$\mathrm{PhD}$} & & & & & -1.3230 & & & & -4.7743 & & -0.0947 \\
\hline & & & & & $(6.7856)$ & & & & (7.3299) & & $(7.1254)$ \\
\hline \multirow[t]{2}{*}{ Tenured } & & & & & & -5.8198 & & & -5.8905 & & -2.9590 \\
\hline & & & & & & (11.1770) & & & $(12.9515)$ & & $(12.7168)$ \\
\hline \multirow[t]{2}{*}{ Top quartile } & & & & & & & -17.1309 & & & & -18.4847 \\
\hline & & & & & & & (11.0982) & & & & $(11.5512)$ \\
\hline \multirow[t]{2}{*}{ Age $30-34$ yr } & & & & & & & & 14.1674 & $16.5823^{*}$ & & $18.3347 * *$ \\
\hline & & & & & & & & $(9.3943)$ & $(9.1543)$ & & (8.9989) \\
\hline \multirow[t]{2}{*}{ Age $35+$ yr } & & & & & & & & 6.5461 & 11.0329 & & 15.6880 \\
\hline & & & & & & & & (10.2797) & (12.3439) & & $(12.2976)$ \\
\hline \multirow[t]{2}{*}{ European PhD } & & & & & & & & & & -6.3535 & -5.6572 \\
\hline & & & & & & & & & & (13.4819) & $(13.5561)$ \\
\hline \multirow[t]{2}{*}{ N. American PhD } & & & & & & & & & & -10.3917 & -10.3855 \\
\hline & & & & & & & & & & $(16.7421)$ & $(16.2366)$ \\
\hline Observations & 665 & 665 & 665 & 665 & 665 & 665 & 665 & 665 & 665 & 665 & 665 \\
\hline
\end{tabular}

Notes: $K=2$; Robust standard errors are in parentheses; *** $p<0.01, * * p<0.05, * p<0.1$. 
To investigate the extent to which different groups of the treated are affected by the treatment, in the following specifications we include various subsets of confounders we also used to estimate the propensity scores in the first-step regression. In the second specification reported in Table 9, we include the dummy variable married. The coefficient of the constant term thus estimates the motherhood effect for women who were neither married nor in a committed relationship before they had their first child. Note that this does not mean that these women necessarily became unmarried mothers. Many of them may have married afterward. Some women, however, may have deliberately chosen to raise a child on their own. In any event, when interpreting the estimated effect we should be aware that not being married at the brink of pregnancy may be an indicator for unplanned motherhood. The estimate indicates either a statistically significant negative effect of single or unplanned motherhood. The effect is sizable: It amounts to somewhat more than the annual research output of the average woman of childbearing age. That is, single or unplanned motherhood reduces the research output in the three years following childbirth by about one-third. For married women the estimate of the motherhood effect results from adding the estimated coefficients of the constant term and the dummy indicating wedlock. The effect is close to zero, implying that married women or women living in a stable relationship, on average, do not have any drop in research productivity in the three years following childbirth. Again, we suspect that this effect is not completely driven by marriage, but rather is derives to some extent from planned motherhood. Women who plan to have a child thus manage to organize or reorganize their lives in such a way that research and motherhood are compatible.

Highly educated women are known to marry highly educated men (Costa and Kahn, 2000), and well-educated husbands may be better able to support a family, either because they are more likely to be hands-on fathers or because the higher income makes child care services more affordable. In the third column of Table 9 we thus test if the positive effect of marriage depends on the education of the husband. The estimated coefficient of the marriage dummy becomes somewhat smaller and loses statistical significance if the husband has at least a college education. The estimated effect of a college-educated husband is, per se, not strong and statistically insignificant, but controlling for college-educated husbands somewhat reduces the explanatory power of marriage (or planned motherhood).

In column four of Table 9 we include dummy variables describing the women's information about the availability of day care services, the omitted reference group consists of those women who did not inform themselves. The estimated coefficient of the constant term thus measures the reduction in research productivity of those mothers who did not inform themselves about whether day care services were available. Again, not knowing about day care services probably captures some dimension of unplanned motherhood. In any event, the estimated coefficient is statistically significant and of the same order of 
magnitude as in column (2) and disappears for mothers who were aware of what to expect. We thus conclude that only women surprised by motherhood or the consequences thereof had suffered a significant reduction in research productivity. ${ }^{10}$

Columns (4) to (7) of Table 9 include, step by step, the variables describing academic success. It transpires that a $\mathrm{PhD}$ degree and tenure status do not influence the size of the motherhood effect. However, male economists who do not have tenure yet become more productive after fathering a child. The respective coefficient in column (6) of Table 10 is positive and statistically significant. Men with tenure, on the other hand, do not appear to become more productive; the total effect of fatherhood adds up to zero for this group. ${ }^{11}$

The last variable describing the academic success indicates whether a mother- or father-to-be has already accumulated a substantial oeuvre. Being among the top-quartile researchers before childbirth appears to have an impact on the motherhood effect: The estimate in column (7) of Table 9 is negative but not quite statistically significant at conventional levels. The sizable point estimate is, however, plausible because highly accomplished researchers are likely to work at maximum effort and are therefore much less able to accommodate their new obligations by simply finding and switching to more efficient research routines.

We now turn to demographic subgroups. Column (8) of Table 9 includes two variables indicating the parent's age at which the first child was born. The reference group consists of those mothers who had their first child before 30 years of age. For this group of women we observe a negative, sizable, and statistically significant treatment effect. For mothers who had their first child in their early 30s (i.e., when most academics have their first child), the negative effect disappears; for older first-time mothers, the effect remains negative, but it is much smaller and lacks statistical significance.

Since age, holding a $\mathrm{PhD}$, and being tenured are correlated with each other, we included all of these variables in column (9) of Table 9. Achieving the career goals of a $\mathrm{PhD}$ degree and tenure increases, as expected, the negative motherhood effect, but the respective estimates are far from statistically significant. The pattern of the motherhood effect across age groups, however, is not affected by the inclusion of these variables. The result that becoming a mother too early is detrimental to research productivity, whereas first motherhood at the "proper" (career) age does not appear to be terribly harmful, thus proves rather robust. ${ }^{12}$

${ }^{10}$ Interestingly, this effect disappears when we use the CF and RF indices to measure research output (see Tables E.15 and E.17). The coefficient of the constant term in column (4) is also significantly different from zero for men but positive if we use the RW index to measure research output (Table E.14).

${ }^{11}$ Tables E.16 and E.18 show the difference between nontenured and tenured male economists becomes more pronounced when we assign journal articles to the years in which they were actually published.

${ }^{12}$ For men, after including the age and $\mathrm{PhD}$ dummies, lack of tenure no longer appears to induce a positive fatherhood effect. However, this changes when we use the CF and RF indices based on journal publication years: The negative effect of fatherhood on research output of men who have already been granted tenure 
Table 10: Semiparametric Difference-In-Difference Estimates of The EFFeCt of Parenthood for Men (CW IndeX)

\begin{tabular}{|c|c|c|c|c|c|c|c|c|c|c|c|}
\hline Variables & (1) & (2) & (3) & (4) & (5) & (6) & (7) & (8) & (9) & (10) & (11) \\
\hline Constant & $\begin{array}{c}6.1113 \\
(4.0060)\end{array}$ & $\begin{array}{l}1.4218 \\
(7.0473)\end{array}$ & $\begin{array}{c}2.9364 \\
(7.5066)\end{array}$ & $\begin{array}{c}9.8894 \\
(6.1256)\end{array}$ & $\begin{array}{c}0.7049 \\
(3.8222)\end{array}$ & $\begin{array}{l}7.5413^{*} \\
(4.2796)\end{array}$ & $\begin{array}{c}4.6301 \\
(3.1858)\end{array}$ & $\begin{array}{l}-0.7903 \\
(8.2185)\end{array}$ & $\begin{array}{l}-2.6399 \\
(7.1776)\end{array}$ & $\begin{array}{c}2.9509 \\
(7.5351)\end{array}$ & $\begin{array}{c}0.1758 \\
(13.2564)\end{array}$ \\
\hline Married & & $\begin{array}{c}8.1946 \\
(8.4086)\end{array}$ & $\begin{array}{l}13.1172 \\
(9.9963)\end{array}$ & & & & & & & & $\begin{array}{c}12.7024 \\
(10.0153)\end{array}$ \\
\hline Spouse college & & & $\begin{array}{l}-9.9641 \\
(9.8601)\end{array}$ & & & & & & & & $\begin{array}{r}-11.2849 \\
(9.6712)\end{array}$ \\
\hline Day care available & & & & $\begin{array}{l}-3.9866 \\
(7.9338)\end{array}$ & & & & & & & $\begin{array}{l}-5.8461 \\
(7.6601)\end{array}$ \\
\hline Day care unavailable & & & & $\begin{array}{c}-6.3062 \\
(12.2790)\end{array}$ & & & & & & & $\begin{array}{c}-8.9443 \\
(12.5768)\end{array}$ \\
\hline $\mathrm{PhD}$ & & & & & $\begin{array}{c}7.3351 \\
(6.5686)\end{array}$ & & & & $\begin{array}{c}6.8493 \\
(9.0547)\end{array}$ & & $\begin{array}{c}5.3281 \\
(8.8262)\end{array}$ \\
\hline Tenured & & & & & & $\begin{array}{c}-6.4795 \\
(11.5790)\end{array}$ & & & $\begin{array}{c}-9.8828 \\
(11.6902)\end{array}$ & & $\begin{array}{l}-10.2795 \\
(11.9105)\end{array}$ \\
\hline Top quartile & & & & & & & $\begin{array}{c}5.4301 \\
(12.2244)\end{array}$ & & & & $\begin{array}{c}5.3622 \\
(12.4371)\end{array}$ \\
\hline Age $30-34$ yr & & & & & & & & $\begin{array}{c}9.2845 \\
(10.4103)\end{array}$ & $\begin{array}{c}7.2704 \\
(11.8734)\end{array}$ & & $\begin{array}{c}6.8401 \\
(11.9516)\end{array}$ \\
\hline Age $35+\mathrm{yr}$ & & & & & & & & $\begin{array}{c}7.5467 \\
(11.0272)\end{array}$ & $\begin{array}{c}7.1188 \\
(13.6864)\end{array}$ & & $\begin{array}{c}4.9568 \\
(14.1726)\end{array}$ \\
\hline European $\mathrm{PhD}$ & & & & & & & & & & $\begin{array}{c}1.9435 \\
(8.6185)\end{array}$ & $\begin{array}{c}1.1387 \\
(9.0521)\end{array}$ \\
\hline N. American PhD & & & & & & & & & & $\begin{array}{c}5.8027 \\
(12.0868)\end{array}$ & $\begin{array}{c}3.4258 \\
(11.4614)\end{array}$ \\
\hline Observations & 1,459 & 1,459 & 1,459 & 1,459 & 1,459 & 1,459 & 1,459 & 1,459 & 1,459 & 1,459 & 1,459 \\
\hline
\end{tabular}

Notes: $K=4$; Robust standard errors are in parentheses; *** $p<0.01, * * p<0.05, * p<0.1$. 
Including the continent variables to control for cultural background (column(10) in Tabel 9) does not change the picture. In column (11), we finally control for all of our confounders. The estimates confirm our previous results. The motherhood effect for the default group is substantial (almost two years of average annual output) but is not quite statistically significant. Even taking this estimate at face value, we find, however, that the motherhood effect is substantially reduced if the mother is at least 30 years old when her first child is born. If she is between 30 and 34 years old, the motherhood effect is reduced by two-thirds (this effect is statistically significant). Moreover, if the mother is married (or lives in a committed relationship), the effect is reduced by one-half, and if pregnancy is planned (as indicated by the mother's awareness of the availability of day care facilities before pregnancy), by one-third. We thus conclude that having a first child need not doom an academic career. Especially for top researchers, motherhood may reduce research productivity to some extent, but, if planned carefully and responsibly, it usually results in little more than a vaguely perceptible loss of research output.

\section{Conclusion}

Regressing research productivity on the family situation of economists, we find in our entire sample of about 10,000 male and female economists that men's productivity is not associated with their family situation in an economically significant manner. For women with young children, however, we estimate an associated productivity loss of $15 \%$ to $17 \%$ compared with women without children. For families with more than one child, we find that a mother's first child is not associated with a statistically significant loss in her productivity. The point estimate of the productivity cost of a first child amounts to $9.5 \%$, the marginal productivity cost of a second child $12.5 \%$, and of a third child $11 \%$. Thus, two preteens are associated, on average, with a productivity loss of $22 \%$, and three preteens with an average loss of $33 \%$. Both of these losses are statistically significant. Economically, they imply that a mother of three children has, on average, a research record reflecting a loss of four years of research output by the time all of her children have reached their teens. The respective output loss of a mother of two children amounts to about two and a half years.

We readily admit that these estimates are subject to at least two types of potential biases. The first one relates to how we date research efforts. The ideal approach to dating research efforts that result in a countable research achievement (in our case, a journal article) would be to use the period in which the effort was made. Lacking this information, we resort to what we consider a second-best solution and use in our preferred measure of research productivity the year in which the first working paper version of the journal arti-

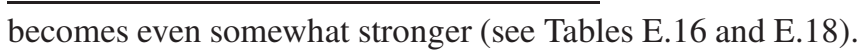


cle appeared. That is, we implicitly assume that in economics each piece of research is, upon completion, immediately communicated in the form of a working paper. However, this is not always the case, and even if such a working paper version always existed, it need not be recorded in RePEc. When we do not find a working paper record in RePEc, in absence of a better alternative, we thus need to use the date of the final journal publication. Since lengthy publication lags in economics are not uncommon, and because working papers are sometimes not published immediately upon completion of a research project, we cannot exclude the possibility that some mothers-to-be completed research projects before conception but our dating method dates these efforts after childbirth. In such cases, preconception productivity is underestimated and post-childbirth productivity is overestimated, which means that our estimate of the motherhood gap in productivity would be downward biased.

The second bias rests on the simple observation that job effort may depend on family planning. A woman who aspires to an academic career and wishes to have children will certainly plan ahead and try to optimize the timing of her professional and family-related actions: She will make an attempt to rear her children when it is least damaging for her academic career and she will also gear her professional efforts to her family objectives. This mutual dependence of the two life plans immediately suggests that a mother-to-be will gear her research output profile toward gaining a firm foothold in academia before having her first child. That is, she will strive to accumulate an oeuvre that allows her to continue smoothly on her career path even though pregnancy, childbirth, and motherhood are likely to impede the flow or her research output for some time. Given this incentive for a strategic career design, female scientists who plan to eventually have a family may likely shift some of the effort required for career advancement to their pre-motherhood period of life to be in a better position to reduce their professional obligations after childbirth. Such behavior gives rise to overestimating the "normal" productivity of childless women and, as a consequence, overestimates the motherhood effect on productivity.

Our estimates may thus be fraught with two biases working in opposite directions. The bias derived from strategic redeployment of work effort most likely carries more weight than the measurement bias because "publication spillovers" can affect only a small part of the period of parenting - the very beginning thereof — whereas work effort can be shifted over a few years. We therefore contend that our estimates, if anything, probably describe an upper bound of the motherhood effect.

Since the family gaps in research productivity estimated with simple regressions do not necessarily describe causal effects, we further investigate the effect of a first child by using a smaller sample of economists from a more recent cohort. In this sample we include all respondents to our questionnaire survey whose first child was born between 2004 and 2007; moreover, we include all respondents who had no children when the 
survey was taken but could have had a child in the 2004-07 period, given their age. For this reduced sample of economists we use all pretreatment background characteristics likely to affect both the fertility decision and research productivity as confounders. In a first step we calculate propensity scores to account for selection into parenthood, in a second one we then compute the treatment effects of parenthood by allowing the treatment effect to vary by association with the confounders. Even if this identification strategy does not completely dismiss any concerns about the endogenous timing of parenthood, it allows us to relax the common trend assumption and to condition the parenthood effect on a large number of determinants likely to influence research productivity.

For untenured men and fathers of twins, the effect of fatherhood on research productivity is positive but not robust to inclusion of other confounders. A positive and robust fatherhood effect would have been consistent with the study by Nock (1998) that finds that fathers work longer hours, perhaps because of a new sense of responsibility induced by fatherhood. In academia, however, the safest and most promising way for a young economist to earn a salary that sustains a family is often to leave academia. Therefore, the fact that we do not observe a clear positive effect of fatherhood on research productivity in our sample of survivors is perhaps not surprising.

For women, the unconditional effect of motherhood is zero. However, we observe a negative effect for women who become mothers before they reach the age of 30; the effect amounts to about $13 \%$. Women who become mothers in the 30- to 34-year age bracket fare substantially better; having an only child at that time of their careers does not appear to be detrimental to their research productivity. The age at first motherhood is ultimately an important determinant of the family gap in productivity; the coefficient of the respective indicator variable is of substantial size, highly significant, and robust to model specification.

We also find that women who were not in a marriage or committed relationship and were uninformed about the availability of childcare facilities before becoming pregnant had an economically and statistically significant decrease in research productivity after childbirth. We interpret these indicators as signifying unintended pregnancy. Accepting this interpretation would then imply that unintended pregnancy reduces research productivity by $13 \%$ to $17 \%$. All of these results suggest that a first child need not destroy any academic career plans. Female academics who carefully project ahead and responsibly orchestrate their private lives appear to be well able to cope with motherhood-at least when they have only one child.

In summary, we conclude that a motherhood bonus for a single child amounting to $10 \%$ of the mother's documented annual research output in each year until the child becomes a teenager would surely compensate for the related reduction in research productivity. This bonus is based on an upper bound estimate for women who make an informed 
fertility decision and carefully schedule their family life. For mothers of two or three children, corresponding estimates are fraught with more uncertainty. Our estimates of a $10 \%$ bonus for each preteen child may, however, serve as an evidence-based benchmark for further considerations.

There is widespread conviction that motherhood is extremely costly in terms of professional career advancement. In particular, it is often argued that the only way for young women to make a challenging career is to remain childless. Our study of the academic labor market arrives at a somewhat less dreary picture: We do not observe a family gap in research productivity among female academic economists. Moreover, motherhoodinduced decreases in research productivity are less pronounced than usually purported. We nevertheless observe associated productivity losses that can be quite sizable, particularly for mothers with several children. This observation raises the question of whether these losses should be acknowledged in tenure and promotion decisions-for example, with an adequate motherhood bonus. In our study, we do not address this issue. We rather content ourselves to providing some empirical evidence that may be helpful in designing suitable regulatory guidelines.

\section{References}

ABADIE, A. (2005): "Semiparametric Difference-in-Differences Estimators," Review of Economic Studies, 72(1), 1-19.

Adda, J., C. Dustmann, And K. Stevens (2011): “The Career Costs of Children," Discussion paper.

Aguero, J. M., And M. S. Marks (2008): "Motherhood and Female Labor Force Participation: Evidence from Infertility Shocks," American Economic Review, 98(2), 500-504.

Angrist, J. D., And W. N. Evans (1998): “Children and Their Parents' Labor Supply: Evidence from Exogenous Variation in Family Size," American Economic Review, 88(3), 450-77.

Angrist, J. D., And J.-S. PischKe (2008): Mostly Harmless Econometrics: An Empiricist's Companion. Princeton University Press.

Azoulay, P., J. S. Graff Zivin, And G. MANSO (2011): "Incentives and creativity: evidence from the academic life sciences," RAND Journal of Economics, 42(3), 527554. 
Bertrand, M., C. Goldin, and L. F. Katz (2010): "Dynamics of the Gender Gap for Young Professionals in the Financial and Corporate Sectors," American Economic Journal: Applied Economics, 2(3), 228-55.

Black, D. A., A. M. Haviland, S. G. Sanders, and L. J. TAYlor (2008): “Gender wage disparities among the highly educated," Journal of Human Resources, 43(3), 630659.

Conley, J. P., M. J. Crucini, R. A. Driskill, And A. S. Onder (2013): "Incentives and the Effects of Publication Lags on Life Cycle Research Productivity in Economics," Economic Inquiry, 51(2), 1251-1276.

CostA, D. L., And M. E. KAHN (2000): "Power Couples: Changes In The Locational Choice Of The College Educated, 1940-1990," The Quarterly Journal of Economics, 115(4), 1287-1315.

Coupé, T. (2003): "Revealed Performances: Worldwide Rankings of Economists and Economics Departments, 1990-2000,' Journal of the European Economic Association, 1(6), 1309-1345.

Cristia, J. P. (2008): “The Effect of a First Child on Female Labor Supply: Evidence from Women Seeking Fertility Services," Journal of Human Resources, 43(3), 487510.

Ellison, G. (2002): “The Slowdown of the Economics Publishing Process," Journal of Political Economy, 110(5), 947-993.

Faggian, A., And M. Della GiUsta (2008): "An educated guess: gender pay gaps in academia," Discussion paper, University of Reading.

Gibson, J., D. L. Anderson, And J. Tressler (2012): "Which Journal Rankings Best Explain Academic Salaries? Evidence from the University of California," Working Papers in Economics 12/10, University of Waikato, Department of Economics.

Ginther, D. K., And S. Kahn (2004): "Women in Economics: Moving Up or Falling Off the Academic Career Ladder?," Journal of Economic Perspectives, 18(3), 193-214.

Goldin, C. (1989): "Life-Cycle Labor-Force Participation of Married Women: Historical Evidence and Implications," Journal of Labor Economics, 7(1), 20-47.

Goodwin, T. H., And R. D. SAuer (1995): "Life Cycle Productivity in Academic Research: Evidence from Cumulative Publication Histories of Academic Economists," Southern Economic Journal, 61(3), 728-743. 
Hamermesh, D. S. (2013): "Six Decades of Top Economics Publishing: Who and How?," Journal of Economic Literature, 51(1).

Hamermesh, D. S., G. E. Johnson, And B. A. Weisbrod (1982): "Scholarship, citations and salaries: Economic rewards in economics," Southern Economic Journal, pp. 472-481.

Hausman, J., B. H. Hall, and Z. Griliches (1984): "Econometric Models for Count Data with an Application to the Patents-R\&D Relationship," Econometrica, 52(4), 909-38.

Hirano, K., G. W. Imbens, And G. Ridder (2003): "Efficient Estimation of Average Treatment Effects Using the Estimated Propensity Score,” Econometrica, 71(4), 11611189.

HunT, J. (2010): “Why Do Women Leave Science and Engineering?, NBER Working Papers 15853, National Bureau of Economic Research, Inc.

Joecks, J., K. Pull, And U. Backes-Gellner (2013): "Childbearing and (Female) Research Productivity - A Personnel Economics Perspective on the Leaky Pipeline," Journal of Business Economics, forthcoming.

Kahn, S. (1993): "Gender Differences in Academic Career Paths of Economists," American Economic Review, 83(2), 52-56.

KaHn, S. B. (1995): "Women in the Economics Profession," Journal of Economic Perspectives, 9(4), 193-206.

Kaufman, G., And P. Uhlenberg (2000): "The Influence of Parenthood on the Work Effort of Married Men and Women," Social Forces, 78(3), 931-947.

Kim, E. H., A. Morse, And L. Zingales (2009): "Are elite universities losing their competitive edge?," Journal of Financial Economics, 93(3), 353-381.

LI, Q., AND J. S. RACINE (2006): "Nonparametric Econometrics: Theory and Practice," Princeton University Press.

MARKuSSEn, S., And M. STRøM (2013): “The effects of motherhood,” Working paper, Ragnar Frisch Centre for Economic Research.

Martin, J. A., B. E. Hamilton, And M. Osterman (2012): “Three Decades of Twin Births in the United States, 1980-2009," Data Brief 80, National Center for Health Statistics. 
Mason, M. A., N. Wolfinger, And M. Goulden (2013): "Do Babies Matter?," Rutgers University Press.

McDowell, J. M., L. D. Singell, and M. Stater (2006): “Two to tango? Gender differences in the decisions to publish and coauthor," Economic Inquiry, 44(1), 153168.

Miller, A. (2011): "The effects of motherhood timing on career path," Journal of Population Economics, 24(3), 1071-1100.

Nock, S. L. (1998): Marriage in Men's Lives. Oxford University Press.

Plümper, T., And F. Schimmelfennig (2007): "Wer wird Prof - und wann? Berufungsdeterminanten in der deutschen Politikwissenschaft," Politische Vierteljahreszeitschrift, 48(1), 97-117.

Rauber, M., and H. W. Ursprung (2008): "Life Cycle and Cohort Productivity in Economic Research: The Case of Germany," German Economic Review, 9(4), 431456.

RhoAds, S. E., And C. H. RhoAds (2012): "Gender roles and infant/toddler care: Male and female professors on the tenure track," Journal of Social, Evolutionary and Cultural Psychology, 6(1), 13-31.

Santos Silva, J. M. C., And S. Tenreyro (2006): "The Log of Gravity," The Review of Economics and Statistics, 88(4), 641-658.

SAUER, R. D. (1988): "Estimates of the returns to quality and coauthorship in economic academia," The Journal of Political Economy, pp. 855-866.

Schiebinger, L., A. D. Henderson, And S. K. Gilmartin (2008): "Dual-Career Academic Couples: What Universities Need to Know," Discussion paper.

Schulze, G. G., S. WARning, And C. Wiermann (2008): "What and how long does it take to get tenure? The case of economics and business administration in Austria, Germany and Switzerland," German Economic Review, 9(4), 473-505.

Seiler, C., And K. Wohlrabe (2011): "Ranking Economists on the Basis of Many Indicators: An Alternative Approach Using RePEc Data," Discussion paper.

SimOnsen, M., AND L. SKIPPER (2006): "The costs of motherhood: an analysis using matching estimators," Journal of Applied Econometrics, 21(7), 919-934.

WALdFogel, J. (1998): “Understanding the 'Family Gap' in Pay for Women with Children," Journal of Economic Perspectives, 12(1), 137-56. 
WARD, M. (2001): “The gender salary gap in British academia," Applied Economics, 33(13), 1669-1681.

Weichselbaumer, D., And R. Winter-Ebmer (2005): "A Meta-Analysis of the International Gender Wage Gap,” Journal of Economic Surveys, 19(3), 479-511.

Wolfinger, N. H., M. A. Mason, And M. Goulden (2008): "Problems in the pipeline: Gender, marriage, and fertility in the ivory tower," The Journal of Higher Education, 79(4), 388-405.

WoOldRIDGE, J. M. (1999): "Distribution-free estimation of some nonlinear panel data models," Journal of Econometrics, 90(1), 77-97.

ZIMMERMANN, C. (2012): “Academic rankings with RePEc,” Discussion paper. 


\section{A Questionnaire}

- Personal details

1. Gender: Female, Male

2. Year of birth:

3. Number of children

If no children, skip to question 4.

a. Year of birth of children:

Child 1

Child 2

Child 3

Child 4

Child 5

b. Were you married or in a marriage-like relationship at the beginning of the first pregnancy?

Yes, No

c. Specify the level of education of your spouse or partner at the beginning of the first pregnancy: Less than high school, High school diploma, Bachelor degree, Masters degree, Doctoral degree, No spouse/partner

4. Were you married or in a marriage-like relationship in 2009 ?

Yes, No

5. Specify the level of education of your spouse or partner in 2009: Less than high school, High school diploma, Bachelor degree, Masters degree, Doctoral degree, No spouse/partner

6. Were you married or in a marriage-like relationship in 2007 ?

Yes, No

7. Specify the level of education of your spouse or partner in 2007: Less than high school, High school diploma, Bachelor degree, Masters degree, Doctoral degree, No spouse/partner

- Educational and career details

8. In which year did you obtain or do you expect to obtain your doctoral degree?

9. In which country have you obtained or do you plan to obtain your doctoral degree?

If United States or Canada, please specify state or province.

10. Type of current employment:

$\mathrm{PhD}$-granting university, Masters-granting university, Baccalaureate-granting university, Government or central bank, Nongovernment policy, Private, None 
11. In which country are you currently employed?

If United States or Canada, please specify state or province.

12. In which country were you employed at the beginning of the first pregnancy?

If United States or Canada, please specify state or province.

13. In which country were you employed in 2009 ?

If United States or Canada, please specify state or province.

14. In which country were you employed in 2007 ?

If United States or Canada, please specify state or province.

15. Have you been granted tenure?

Yes, No

If yes, when?

If not, when do you expect it?

16. Have you spent at least a week visiting a research institution at least $300 \mathrm{~km}(180$ miles) away from your home since 2009?

Yes, No

If yes, how many weeks in all since 2009 ?

17. If you are a parent, have you spent at least a week visiting a research institution at least $300 \mathrm{~km}$ (180 miles) away from your home within the two years following your first child's birth/adoption?

Yes, No

If yes, how many weeks in all over the two years?

- Institutional Circumstances

18. Are day care/kindergarden services offered in the area where you are currently working?

Yes, No, I do not know

19. Were day care/kindergarden services offered in the area where you were working in 2009 ?

Yes, No, I do not know

20. Were da ycare/kindergarden services offered in the area where you were working in 2007 ?

Yes, No, I do not know

If you have no children, please skip to question 21.

a. And the beginning of the first pregnancy?

Yes, No, I do not know 
b. Do you or your partner's parents live within $32 \mathrm{~km}$ (20 miles) from your home currently?

Yes, No

c. Did you or your partner's parents live within $32 \mathrm{~km}$ (20 miles) from your home in 2009 ?

Yes, No

d. Did you or your partner's parents live within $32 \mathrm{~km}$ (20 miles) from your home in 2007 ?

Yes, No

e. Did you or your partner's parents live within $32 \mathrm{~km}$ (20 miles) from your home at the beginning of the first pregnancy?

Yes, No

f. How easy was it for you to find opportunities to let others take care of your children?

Very good, Good, Wished it had been easier, Have not had the possibility

g. Did/do you use day care service or kindergarden? Yes, No

h. After the arrival of your 1st child, how long was your parental leave, in weeks?

i. After the arrival of your 2nd child, how long was your parental leave, in weeks?

j. After the arrival of your 3rd child, how long was your parental leave, in weeks?

k. After the arrival of your 4th child, how long was your parental leave, in weeks?

1. After the arrival of your 5th child, how long was your parental leave, in weeks?

m. Forgone opportunities: do you think that, during the year after the children's births/adoptions: You were not able to attend any conferences or seminars, You could attend significantly fewer conferences and seminars than otherwise, Raising a child did not keep you from attending conferences and seminars

n. Have you ever chosen not to take a sabbatical leave due to family obligations? Not applicable, Yes, No

o. All in all, how did you and you partner split the time raising your children during their first year?

p. Which of the following possible changes did you observe in your working style after the arrival of your first child? I used the time more efficiently, I often felt tired and distracted, No change

21. Does your current institution use a tenure clock (a policy of evaluation for tenure after a predetermined period)?

Yes, No

If no, please submit all your answers with the button at the very bottom of the form.

22. Is the tenure clock extended for the arrival of a child?

Yes, No, Sometimes 
23. Did you obtain a tenure clock extension after the arrival of a child? Yes, No, Not applicable

24. If you already went through a tenure process after an extension, compared with a process without child and extension: Not applicable, Standards were a lot higher, Standards were higher, Standards were similar, Standards were lower, Standards were a lot lower

25. Have you delayed having children because of tenure considerations, or do you expect to? Yes, No 


\section{B Additional descriptive statistics}

Table B.1: PhD COUnTRY

\begin{tabular}{lrr}
\hline \hline Country & Number & Percent \\
\hline U.S.A. & 3,478 & 34.99 \\
U.K. & 956 & 9.62 \\
Germany & 713 & 7.17 \\
France & 707 & 7.11 \\
Italy & 650 & 6.54 \\
Spain & 454 & 4.57 \\
Netherlands & 361 & 3.63 \\
Belgium & 237 & 2.38 \\
Sweden & 218 & 2.19 \\
Canada & 210 & 2.11 \\
Australia & 163 & 1.64 \\
Romania & 140 & 1.41 \\
Switzerland & 129 & 1.30 \\
India & 100 & 1.01 \\
Unspecified & 132 & 1.33 \\
Other & 1,291 & 12.99 \\
\hline \multicolumn{3}{r}{} \\
\hline \hline Notes: List includes the 14 count- \\
ries with at least 100 respondents.
\end{tabular}


C Lifecycle patterns 
Table C.1: Women And Men With PhDs Before 1990: Different Numbers of Children, CW MeAsure

\begin{tabular}{|c|c|c|c|c|c|c|}
\hline & (1) & (2) & (3) & (4) & (5) & (6) \\
\hline Variables & Women no kids & Women 1 kid & Women $>1$ kids & Men no kids & Men 1 kid & Men $>1$ kids \\
\hline \multirow[t]{2}{*}{ Constant } & $1.9028 * * *$ & $1.2925^{* * *}$ & $1.9942 * * *$ & $2.4412 * * *$ & $2.0721 * * *$ & $2.3453 * * *$ \\
\hline & $(0.1990)$ & $(0.2854)$ & $(0.1265)$ & $(0.1138)$ & $(0.0947)$ & $(0.0481)$ \\
\hline \multirow[t]{2}{*}{ Career } & $0.2841 * * *$ & $0.4448 * * *$ & $0.3919 * * *$ & $0.3750 * * *$ & $0.4757 * * *$ & $0.3803 * * *$ \\
\hline & $(0.0858)$ & $(0.0947)$ & $(0.0564)$ & $(0.0526)$ & $(0.0375)$ & $(0.0236)$ \\
\hline \multirow[t]{2}{*}{ Career $^{2}$} & $-0.0344 * *$ & $-0.0379 * *$ & $-0.0530 * * *$ & $-0.0558 * * *$ & $-0.0609 * * *$ & $-0.0456 * * *$ \\
\hline & $(0.0161)$ & $(0.0175)$ & $(0.0100)$ & $(0.0095)$ & $(0.0066)$ & $(0.0040)$ \\
\hline \multirow[t]{2}{*}{ Career $^{3}$} & $1.72 \times 10^{-3}$ & $9.76 \times 10^{-4}$ & $2.95 \times 10^{-3 * * *}$ & $3.36 \times 10^{-3 * * *}$ & $3.27 \times 10^{-3 * * *}$ & $2.28 \times 10^{-3 * * *}$ \\
\hline & $\left(1.12 \times 10^{-3}\right)$ & $\left(1.13 \times 10^{-3}\right)$ & $\left(7.00 \times 10^{-4}\right)$ & $\left(6.56 \times 10^{-4}\right)$ & $\left(4.63 \times 10^{-4}\right)$ & $\left(2.60 \times 10^{-4}\right)$ \\
\hline \multirow[t]{2}{*}{ Career $^{4}$} & $-3.67 \times 10^{-5}$ & $-6.35 \times 10^{-7}$ & $-7.15 \times 10^{-5 * * *}$ & $-8.82 \times 10^{-5 * * *}$ & $-7.93 \times 10^{-5 * * *}$ & $-5.12 \times 10^{-5 * * *}$ \\
\hline & $\left(3.56 \times 10^{-5}\right)$ & $\left(4.02 \times 10^{-5}\right)$ & $\left(2.04 \times 10^{-5}\right)$ & $\left(1.88 \times 10^{-5}\right)$ & $\left(1.34 \times 10^{-5}\right)$ & $\left(7.15 \times 10^{-6}\right)$ \\
\hline \multirow[t]{2}{*}{ Career $^{5}$} & $2.59 \times 10^{-7}$ & $-1.64 \times 10^{-7}$ & $6.21 \times 10^{-7 * * *}$ & $8.2 \times 10^{-7 * * *}$ & $7.04 \times 10^{-7 * * *}$ & $4.22 \times 10^{-7 * * *}$ \\
\hline & $\left(3.76 \times 10^{-7}\right)$ & $\left(4.21 \times 10^{-7}\right)$ & $\left(2.07 \times 10^{-7}\right)$ & $\left(1.88 \times 10^{-7}\right)$ & $\left(1.35 \times 10^{-7}\right)$ & $\left(6.93 \times 10^{-8}\right)$ \\
\hline Log likelihood & -19618.638 & -19959.039 & -92021.866 & -89897.411 & -161535.8 & -845966.2 \\
\hline Observations & 1,177 & 1,063 & 4,184 & 3,322 & 6,354 & 28,774 \\
\hline
\end{tabular}

Notes: Poisson estimates; without individual fixed effects; Robust standard errors are in parentheses;

$* * * p<0.01, * * p<0.05, * p<0.1$. 
Table C.2: Women And Men With PhDs Before 1990: DifFerent Numbers of Children, RW MEAsure

\begin{tabular}{|c|c|c|c|c|c|c|}
\hline & (1) & (2) & (3) & (4) & (5) & (6) \\
\hline Variables & Women no kids & Women one kid & Women $>1$ kids & Men no kids & Men one kid & Men $>1$ kids \\
\hline \multirow[t]{2}{*}{ Constant } & $-0.5087 * *$ & $-0.9773 * * *$ & -0.2293 & $0.2554 *$ & $-0.2663 * *$ & $0.1380 * *$ \\
\hline & $(0.2420)$ & $(0.3492)$ & $(0.1462)$ & $(0.1344)$ & $(0.1131)$ & $(0.0560)$ \\
\hline \multirow[t]{2}{*}{ Career } & $0.3185 * * *$ & $0.5142 * * *$ & $0.4094 * * *$ & $0.3710 * * *$ & $0.5110 * * *$ & $0.3801 * * *$ \\
\hline & $(0.0835)$ & $(0.1297)$ & $(0.0680)$ & $(0.0661)$ & $(0.0422)$ & $(0.0280)$ \\
\hline \multirow[t]{2}{*}{ Career $^{2}$} & $-0.0364 * *$ & $-0.0540 * *$ & $-0.0548 * * *$ & $-0.0512 * * *$ & $-0.0655 * * *$ & $-0.0464 * * *$ \\
\hline & $(0.0181)$ & $(0.0244)$ & $(0.0125)$ & (0.0119) & $(0.0077)$ & $(0.0048)$ \\
\hline \multirow[t]{2}{*}{ Career $^{3}$} & 0.0016 & 0.0023 & $0.0030 * * *$ & $0.0028 * * *$ & $0.0034 * * *$ & $0.0023 * * *$ \\
\hline & (0.0014) & (0.0018) & $(0.0009)$ & $(0.0008)$ & $(0.0006)$ & $(0.0003)$ \\
\hline \multirow[t]{2}{*}{ Career $^{4}$} & $-2.36 \times 10^{-5}$ & $-4.53 \times 10^{-5}$ & $-7.12 \times 10^{-5 * * *}$ & $-6.62 \times 10^{-5 * * *}$ & $-8.33 \times 10^{-5 * * *}$ & $-5.23 \times 10^{-5 * * *}$ \\
\hline & $\left(4.59 \times 10^{-5}\right)$ & $\left(5.70 \times 10^{-5}\right)$ & $\left(2.66 \times 10^{-5}\right)$ & $\left(2.35 \times 10^{-5}\right)$ & $\left(1.62 \times 10^{-5}\right)$ & $\left(8.88 \times 10^{-6}\right)$ \\
\hline \multirow[t]{2}{*}{ Career $^{5}$} & $1.07 \times 10^{-7}$ & $3.28 \times 10^{-7}$ & $6.09 \times 10^{-7 * *}$ & $5.74 \times 10^{-7 * *}$ & $7.32 \times 10^{-7 * * *}$ & $4.34 \times 10^{-7 * * *}$ \\
\hline & $\left(5.07 \times 10^{-7}\right)$ & $\left(6.03 \times 10^{-7}\right)$ & $\left(2.78 \times 10^{-7}\right)$ & $\left(2.33 \times 10^{-7}\right)$ & $\left(1.64 \times 10^{-7}\right)$ & $\left(8.66 \times 10^{-8}\right)$ \\
\hline Log likelihood & -2445.8581 & -2582.8762 & -12382.412 & -12643.696 & -20828.953 & -113358.91 \\
\hline Observations & 1,177 & 1,063 & 4,184 & 3,322 & 6,354 & 28,774 \\
\hline
\end{tabular}

Notes: Poisson estimates; without individual fixed effects; Robust standard errors are in parentheses;

$* * * p<0.01, * * p<0.05, * p<0.1$. 


\section{Descriptive statistics treatment analysis}
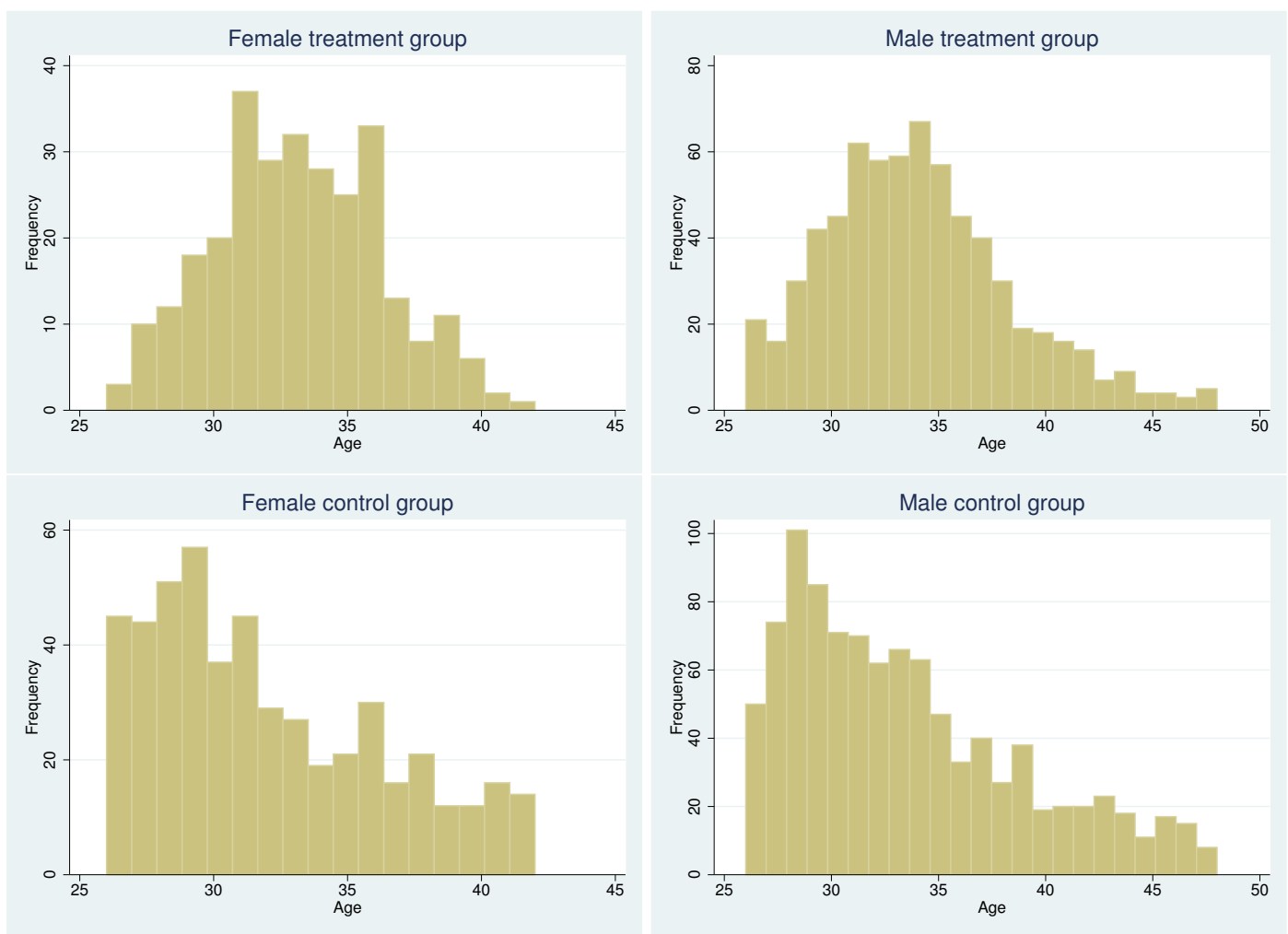

Figure D.1: THE LEFT PANEL SHOWS TWO HISTOGRAMS COMPARING THE AGE DISTRIBUTION IN THE TREATMENT AND CONTROL GROUPS FOR FEMALE RESEARCHERS. THE RIGHT PANEL SHOWS TWO HISTOGRAMS COMPARING THE AGE DISTRIBUTION IN THE TREATMENT AND CONTROL GROUPS FOR MALE RESEARCHERS. 
Table D.1: DESCRIPTIVE STATISTICS

\begin{tabular}{lcccc}
\hline \hline & \multicolumn{2}{c}{ Women } & \multicolumn{2}{c}{ Men } \\
& Treated & Controls & Treated & Controls \\
\hline PhD & 0.8090 & 0.5605 & 0.7481 & 0.6360 \\
Tenured & 0.1875 & 0.1290 & 0.2235 & 0.2076 \\
Top-quartile CW & 0.3021 & 0.2198 & 0.2772 & 0.2311 \\
Married & 0.9792 & 0.5423 & 0.9598 & 0.5031 \\
Spouse no high school & 0.0069 & 0.0161 & 0.0075 & 0.0072 \\
Spouse high school & 0.0278 & 0.0323 & 0.0581 & 0.0368 \\
Spouse college & 0.1285 & 0.1089 & 0.2459 & 0.1534 \\
Spouse masters degree & 0.3681 & 0.2278 & 0.4367 & 0.2607 \\
Spouse PhD & 0.4688 & 0.2298 & 0.2474 & 0.1401 \\
Day care available & 0.7847 & 0.4859 & 0.8152 & 0.5164 \\
Day care unavailable & 0.0521 & 0.3871 & 0.0671 & 0.3824 \\
Day care uninformed & 0.1632 & 0.1270 & 0.1177 & 0.1012 \\
PhD North America & 0.3229 & 0.2923 & 0.3666 & 0.2904 \\
PhD Africa & 0.0000 & 0.0081 & 0.0149 & 0.0041 \\
PhD Asia & 0.0174 & 0.0262 & 0.0462 & 0.0399 \\
PhD Europe & 0.6354 & 0.6391 & 0.5380 & 0.6309 \\
PhD Latin America & 0.0069 & 0.0081 & 0.0134 & 0.0184 \\
PhD Oceania & 0.0174 & 0.0262 & 0.0209 & 0.0164 \\
\hline Observations & 288 & 496 & 671 & 978 \\
\hline \hline
\end{tabular}

Notes: Arithmetic means of dummy variables used to compute propensity scores. 
E Robustness checks 
Table E.1: Lifecycle Productivity (RW Index): Career Year Dummies vs. Fifth-Order Polynomial Approximation

\begin{tabular}{|c|c|c|c|c|c|c|c|}
\hline Variables & $\begin{array}{l}(1) \\
\text { All }\end{array}$ & $\begin{array}{c}\text { (2) } \\
\text { PhD-granting } \\
\text { institutions }\end{array}$ & $\begin{array}{l}(3) \\
\text { All }\end{array}$ & $\begin{array}{c}(4) \\
\text { Women }\end{array}$ & $\begin{array}{l}(5) \\
\text { Men }\end{array}$ & $\begin{array}{c}(6) \\
\text { Women } \\
\text { PhD inst }\end{array}$ & $\begin{array}{c}\text { (7) } \\
\text { Men } \\
\text { PhD inst }\end{array}$ \\
\hline Constant & $\begin{array}{c}-2.6416 * * * \\
(0.2138)\end{array}$ & $\begin{array}{c}-2.5397 * * * \\
(0.2619)\end{array}$ & $\begin{array}{c}0.1831 * * * \\
(0.0238)\end{array}$ & $\begin{array}{c}-0.2001 * * * \\
(0.0577)\end{array}$ & $\begin{array}{c}0.1556^{* * * *} \\
(0.0260)\end{array}$ & $\begin{array}{c}-0.2112 * * * \\
(0.0756)\end{array}$ & $\begin{array}{c}0.3112 * * * \\
(0.0312)\end{array}$ \\
\hline Career & & & $\begin{array}{c}0.3798 * * * \\
(0.0079)\end{array}$ & $\begin{array}{c}0.3529 * * * \\
(0.0146)\end{array}$ & $\begin{array}{c}0.3865^{* * * *} \\
(0.0092)\end{array}$ & $\begin{array}{c}0.4012 * * * \\
(0.0233)\end{array}$ & $\begin{array}{c}0.3949 * * * \\
(0.0131)\end{array}$ \\
\hline Career $^{2}$ & & & $\begin{array}{c}-0.0483 * * * \\
(0.0016)\end{array}$ & $\begin{array}{c}-0.0473 * * * \\
(0.0034)\end{array}$ & $\begin{array}{c}-0.0488 * * * \\
(0.0019)\end{array}$ & $\begin{array}{c}-0.0472 * * * \\
(0.0053)\end{array}$ & $\begin{array}{c}-0.0480 * * * \\
(0.0025)\end{array}$ \\
\hline Career $^{3}$ & & & $\begin{array}{c}2.47 \times 10^{-3 * * *} \\
\left(1.28 \times 10^{-4}\right)\end{array}$ & $\begin{array}{c}2.48 \times 10^{-3 * * *} \\
\left(2.98 \times 10^{-4}\right)\end{array}$ & $\begin{array}{c}2.48 \times 10^{-3} * * * \\
\left(1.43 \times 10^{-4}\right)\end{array}$ & $\begin{array}{c}2.43 \times 10^{-3} * * * \\
\left(4.58 \times 10^{-4}\right)\end{array}$ & $\begin{array}{c}2.39 \times 10^{-3 * * *} \\
\left(1.87 \times 10^{-4}\right)\end{array}$ \\
\hline Career $^{4}$ & & & $\begin{array}{c}-5.6 \times 10^{-5 * * *} \\
\left(4.02 \times 10^{-6}\right)\end{array}$ & $\begin{array}{c}-5.62 \times 10^{-5 * * *} \\
\left(1.02 \times 10^{-5}\right)\end{array}$ & $\begin{array}{c}-5.62 \times 10^{-5 * * *} \\
\left(4.42 \times 10^{-6}\right)\end{array}$ & $\begin{array}{c}-5.01 \times 10^{-5 * * *} \\
\left(1.57 \times 10^{-5}\right)\end{array}$ & $\begin{array}{c}-5.31 \times 10^{-5 * * *} \\
\left(5.73 \times 10^{-6}\right)\end{array}$ \\
\hline Career $^{5}$ & & & $\begin{array}{c}4.65 \times 10^{-7 * * *} \\
\left(4.30 \times 10^{-8}\right)\end{array}$ & $\begin{array}{c}4.51 \times 10^{-7 * * *} \\
\left(1.17 \times 10^{-7}\right)\end{array}$ & $\begin{array}{c}4.66 \times 10^{-7 * * *} \\
\left(4.68 \times 10^{-8}\right)\end{array}$ & $\begin{array}{c}3.64 \times 10^{-7 * *} \\
\left(1.83 \times 10^{-7}\right)\end{array}$ & $\begin{array}{c}4.36 \times 10^{-7 * * *} \\
\left(6.06 \times 10^{-8}\right)\end{array}$ \\
\hline PhD 1990-99 & $\begin{array}{c}-0.4164 * * * \\
(0.0206)\end{array}$ & $\begin{array}{c}-0.4099 * * * \\
(0.0225)\end{array}$ & $\begin{array}{c}-0.4235 * * * \\
(0.0205)\end{array}$ & $\begin{array}{c}-0.5497 * * * \\
(0.0525)\end{array}$ & $\begin{array}{c}-0.4038 * * * \\
(0.0221)\end{array}$ & $\begin{array}{c}-0.3072 * * * \\
(0.0641)\end{array}$ & $\begin{array}{c}-0.3990 * * * \\
(0.0255)\end{array}$ \\
\hline PhD 2000+ & $\begin{array}{c}-0.6638 * * * \\
(0.0254)\end{array}$ & $\begin{array}{c}-0.6371 * * * \\
(0.0284)\end{array}$ & $\begin{array}{c}-0.6594 * * * \\
(0.0254)\end{array}$ & $\begin{array}{c}-0.6848 * * * \\
(0.0597)\end{array}$ & $\begin{array}{c}-0.6675^{* * *} \\
(0.0282)\end{array}$ & $\begin{array}{c}-0.3466 * * * \\
(0.0806)\end{array}$ & $\begin{array}{c}-0.5283 * * * \\
(0.0356)\end{array}$ \\
\hline Female & $\begin{array}{c}-0.5478 * * * \\
(0.0221)\end{array}$ & $\begin{array}{c}-0.5759 * * * \\
(0.0250)\end{array}$ & $\begin{array}{c}-0.5480 * * * \\
(0.0221)\end{array}$ & & & & \\
\hline Tenured & & & & & & $\begin{array}{c}-0.6069 * * * \\
(0.0588)\end{array}$ & $\begin{array}{c}-0.1622 * * * \\
(0.0272)\end{array}$ \\
\hline Career dummies & Yes & Yes & No & No & No & No & No \\
\hline Log likelihood & -385138.96 & -303274.03 & -385785.52 & -60185.39 & -325465.85 & -36485.216 & -221051.4 \\
\hline Observations & 153,425 & 111,962 & 153,425 & 36,951 & 116,474 & 17,999 & 66,327 \\
\hline
\end{tabular}

Notes: Poisson estimates without individual fixed effects; Robust standard errors are in parentheses;

$* * * p<0.01, * * p 0<0.05, * p<0.1$. 
Table E.2: Lifecycle Productivity (CF Index): Career Year Dummies vs. Fifth-Order Polynomial Approximation

\begin{tabular}{|c|c|c|c|c|c|c|c|}
\hline Variables & $\begin{array}{l}(1) \\
\text { All }\end{array}$ & $\begin{array}{c}\text { (2) } \\
\text { PhD-granting } \\
\text { institutions }\end{array}$ & $\begin{array}{l}(3) \\
\text { All }\end{array}$ & $\begin{array}{c}(4) \\
\text { Women }\end{array}$ & $\begin{array}{l}(5) \\
\text { Men }\end{array}$ & $\begin{array}{c}(6) \\
\text { Women } \\
\text { PhD inst }\end{array}$ & $\begin{array}{c}(7) \\
\text { Men } \\
\text { PhD inst }\end{array}$ \\
\hline Constant & $\begin{array}{c}-0.4044 * * * \\
(0.1525)\end{array}$ & $\begin{array}{c}-0.3629 * * * \\
(0.1973)\end{array}$ & $\begin{array}{c}2.0540 * * * \\
(0.0216)\end{array}$ & $\begin{array}{c}1.5890 * * * \\
(0.0509)\end{array}$ & $\begin{array}{c}2.0443 * * * \\
(0.0238)\end{array}$ & $\begin{array}{c}1.6213 * * * \\
(0.0665)\end{array}$ & $\begin{array}{c}2.1974 * * * \\
(0.0292)\end{array}$ \\
\hline Career & & & $\begin{array}{c}0.4233 * * * \\
(0.0073)\end{array}$ & $\begin{array}{c}0.4010^{* * * *} \\
(0.0145)\end{array}$ & $\begin{array}{c}0.4286^{* * * *} \\
(0.0084)\end{array}$ & $\begin{array}{c}0.4398 * * * \\
(0.0252)\end{array}$ & $\begin{array}{c}0.4347 * * * \\
(0.0125)\end{array}$ \\
\hline Career $^{2}$ & & & $\begin{array}{c}-0.0469 * * * \\
(0.0015)\end{array}$ & $\begin{array}{c}-0.0420 * * * \\
(0.0033)\end{array}$ & $\begin{array}{c}-0.0477 * * * \\
(0.0016)\end{array}$ & $\begin{array}{c}-0.0417 * * * \\
(0.0054)\end{array}$ & $\begin{array}{c}-0.0479 * * * \\
(0.0023)\end{array}$ \\
\hline Career $^{3}$ & & & $\begin{array}{c}2.21 \times 10^{-3 * * *} \\
\left(1.10 \times 10^{-4}\right)\end{array}$ & $\begin{array}{c}1.76 \times 10^{-3 * * *} \\
\left(2.76 \times 10^{-4}\right)\end{array}$ & $\begin{array}{c}2.27 \times 10^{-3 * * *} \\
\left(1.21 \times 10^{-4}\right)\end{array}$ & $\begin{array}{c}1.62 \times 10^{-3 * * *} \\
\left(4.37 \times 10^{-4}\right)\end{array}$ & $\begin{array}{c}2.26 \times 10^{-3 * * *} \\
\left(1.63 \times 10^{-4}\right)\end{array}$ \\
\hline Career $^{4}$ & & & $\begin{array}{c}-4.72 \times 10^{-5 * * *} \\
\left(3.36 \times 10^{-6}\right)\end{array}$ & $\begin{array}{c}-2.98 \times 10^{-5 * * *} \\
\left(9.22 \times 10^{-6}\right)\end{array}$ & $\begin{array}{c}-4.89 \times 10^{-5 * * *} \\
\left(3.66 \times 10^{-6}\right)\end{array}$ & $\begin{array}{l}-2.37 \times 10^{-5} \\
\left(1.45 \times 10^{-5}\right)\end{array}$ & $\begin{array}{c}-4.85 \times 10^{-5 * * *} \\
\left(4.85 \times 10^{-6}\right)\end{array}$ \\
\hline Career $^{5}$ & & & $\begin{array}{c}3.71 \times 10^{-7 * * *} \\
\left(3.53 \times 10^{-8}\right)\end{array}$ & $\begin{array}{c}1.5 \times 10^{-7} \\
\left(1.06 \times 10^{-7}\right)\end{array}$ & $\begin{array}{c}3.9 \times 10^{-7 * * *} \\
\left(3.82 \times 10^{-8}\right)\end{array}$ & $\begin{array}{c}6.71 \times 10^{-8} \\
\left(1.66 \times 10^{-7}\right)\end{array}$ & $\begin{array}{c}3.87 \times 10^{-7 * * *} \\
\left(5.01 \times 10^{-8}\right)\end{array}$ \\
\hline PhD 1990-99 & $\begin{array}{c}-0.2029 * * * \\
(0.0166)\end{array}$ & $\begin{array}{c}-0.1921 * * * \\
(0.0180)\end{array}$ & $\begin{array}{c}-0.2121 * * * \\
(0.0166)\end{array}$ & $\begin{array}{c}-0.2531 * * * \\
(0.0426)\end{array}$ & $\begin{array}{c}-0.2033^{* * * *} \\
(0.0179)\end{array}$ & $\begin{array}{c}-0.0979 * \\
(0.0516)\end{array}$ & $\begin{array}{c}-0.1894 * * * \\
(0.0204)\end{array}$ \\
\hline PhD 2000+ & $\begin{array}{c}-0.2771 * * * \\
(0.0210)\end{array}$ & $\begin{array}{c}-0.2690 * * * \\
(0.0233)\end{array}$ & $\begin{array}{c}-0.2709 * * * \\
(0.0210)\end{array}$ & $\begin{array}{c}-0.2112^{* * * *} \\
(0.0498)\end{array}$ & $\begin{array}{c}-0.2893 * * * \\
(0.0233)\end{array}$ & $\begin{array}{l}-0.0134 \\
(0.0641)\end{array}$ & $\begin{array}{c}-0.1857 * * * \\
(0.0287)\end{array}$ \\
\hline Female & $\begin{array}{c}-0.4918 * * * \\
(0.0167)\end{array}$ & $\begin{array}{c}-0.5257 * * * \\
(0.0189)\end{array}$ & $\begin{array}{c}-0.4918^{* * * *} \\
(0.0167)\end{array}$ & & & & \\
\hline Tenured & & & & & & $\begin{array}{c}-0.4459 * * * \\
(0.0459)\end{array}$ & $\begin{array}{c}-0.0813 * * * \\
(0.0222)\end{array}$ \\
\hline Career dummies & Yes & Yes & No & No & No & No & No \\
\hline Log likelihood & -2850584.1 & -2222243 & -2858843.8 & -469148.58 & -2388911.9 & -277233.52 & -1596134.5 \\
\hline Observations & 153,425 & 111,962 & 153,425 & 36,951 & 116,474 & 17,999 & 66,327 \\
\hline
\end{tabular}

Notes: Poisson estimates without individual fixed effects; Robust standard errors are in parentheses;

*** $p<0.01, * * p<0.05, * p<0.1$. 
Table E.3: Lifecycle Productivity (RF Index): CAreer Year Dummies vs. Fifth-Order Polynomial Approximation

\begin{tabular}{|c|c|c|c|c|c|c|c|}
\hline Variables & $\begin{array}{l}(1) \\
\text { All }\end{array}$ & $\begin{array}{c}\text { (2) } \\
\text { PhD-granting } \\
\text { institutions }\end{array}$ & $\begin{array}{l}\text { (3) } \\
\text { All }\end{array}$ & $\begin{array}{c}(4) \\
\text { Women }\end{array}$ & $\begin{array}{l}(5) \\
\text { Men }\end{array}$ & $\begin{array}{c}(6) \\
\text { Women } \\
\text { PhD inst }\end{array}$ & $\begin{array}{c}(7) \\
\text { Men } \\
\text { PhD inst }\end{array}$ \\
\hline Constant & $\begin{array}{c}-2.8703 * * * \\
(0.2442)\end{array}$ & $\begin{array}{c}-2.7583 * * * \\
(0.2980)\end{array}$ & $\begin{array}{c}-0.2160 * * * \\
(0.0284)\end{array}$ & $\begin{array}{c}-0.6878 * * * \\
(0.0662)\end{array}$ & $\begin{array}{c}-0.2272 * * * \\
(0.0314)\end{array}$ & $\begin{array}{c}-0.7056 \text { *** } \\
(0.0882)\end{array}$ & $\begin{array}{l}-0.0458 \\
(0.0383)\end{array}$ \\
\hline Career & & & $\begin{array}{c}0.4610^{* * * *} \\
(0.0111)\end{array}$ & $\begin{array}{c}0.4497 * * * \\
(0.0222)\end{array}$ & $\begin{array}{c}0.4632 * * * \\
(0.0126)\end{array}$ & $\begin{array}{c}0.4881 \text { *** } \\
(0.0366)\end{array}$ & $\begin{array}{c}0.4595^{* * * *} \\
(0.0176)\end{array}$ \\
\hline Career $^{2}$ & & & $\begin{array}{c}-0.0526 * * * \\
(0.0021)\end{array}$ & $\begin{array}{c}-0.0496 * * * \\
(0.0050)\end{array}$ & $\begin{array}{c}-0.0529 * * * \\
(0.0023)\end{array}$ & $\begin{array}{c}-0.0459 * * * \\
(0.0081)\end{array}$ & $\begin{array}{c}-0.0513 * * * \\
(0.0031)\end{array}$ \\
\hline Career $^{3}$ & & & $\begin{array}{c}2.51 \times 10^{-3 * * *} \\
\left(1.54 \times 10^{-4}\right)\end{array}$ & $\begin{array}{c}2.17 \times 10^{-3 * * *} \\
\left(4.13 \times 10^{-4}\right)\end{array}$ & $\begin{array}{c}2.53 \times 10^{-3 * * *} \\
\left(1.69 \times 10^{-4}\right)\end{array}$ & $\begin{array}{l}1.65 \times 10^{-3 * *} \\
\left(6.84 \times 10^{-4}\right)\end{array}$ & $\begin{array}{c}2.42 \times 10^{-3 * * *} \\
\left(2.19 \times 10^{-4}\right)\end{array}$ \\
\hline Career $^{4}$ & & & $\begin{array}{c}-5.39 \times 10^{-5 * * *} \\
\left(4.60 \times 10^{-6}\right)\end{array}$ & $\begin{array}{c}-3.97 \times 10^{-5 * * *} \\
\left(1.39 \times 10^{-5}\right)\end{array}$ & $\begin{array}{c}-5.47 \times 10^{-5 * * *} \\
\left(5.00 \times 10^{-6}\right)\end{array}$ & $\begin{array}{l}-1.88 \times 10^{-5} \\
\left(2.35 \times 10^{-5}\right)\end{array}$ & $\begin{array}{c}-5.17 \times 10^{-5 * * *} \\
\left(6.43 \times 10^{-6}\right)\end{array}$ \\
\hline Career $^{5}$ & & & $\begin{array}{c}4.28 \times 10^{-7 * * *} \\
\left(4.74 \times 10^{-8}\right)\end{array}$ & $\begin{array}{c}2.34 \times 10^{-7} \\
\left(1.60 \times 10^{-7}\right)\end{array}$ & $\begin{array}{c}4.38 \times 10^{-7 * * *} \\
\left(5.12 \times 10^{-8}\right)\end{array}$ & $\begin{array}{l}-4.15 \times 10^{-8} \\
\left(2.79 \times 10^{-7}\right)\end{array}$ & $\begin{array}{c}4.12 \times 10^{-7 * * *} \\
\left(6.56 \times 10^{-8}\right)\end{array}$ \\
\hline PhD 1990-99 & $\begin{array}{c}-0.3825 * * * \\
(0.0208)\end{array}$ & $\begin{array}{c}-0.3753 * * * \\
(0.0227)\end{array}$ & $\begin{array}{c}-0.3922 * * * \\
(0.0207)\end{array}$ & $\begin{array}{c}-0.5142 * * * \\
(0.0535)\end{array}$ & $\begin{array}{c}-0.3729 * * * \\
(0.0223)\end{array}$ & $\begin{array}{c}-0.2837 * * * \\
(0.0646)\end{array}$ & $\begin{array}{c}-0.3691 * * * \\
(0.0257)\end{array}$ \\
\hline $\mathrm{PhD} 2000+$ & $\begin{array}{c}-0.5414 * * * \\
(0.0271)\end{array}$ & $\begin{array}{c}-0.5196 * * * \\
(0.0302)\end{array}$ & $\begin{array}{c}-0.5351 * * * \\
(0.0272)\end{array}$ & $\begin{array}{c}-0.5043 * * * \\
(0.0636)\end{array}$ & $\begin{array}{c}-0.5542 * * * \\
(0.0302)\end{array}$ & $\begin{array}{c}-0.2012 * * \\
(0.0834)\end{array}$ & $\begin{array}{c}-0.4352 * * * \\
(0.0375)\end{array}$ \\
\hline Female & $\begin{array}{c}-0.5399 * * * \\
(0.0221)\end{array}$ & $\begin{array}{c}-0.5697 * * * \\
(0.0250)\end{array}$ & $\begin{array}{c}-0.5399 * * * \\
(0.0222)\end{array}$ & & & & \\
\hline Tenured & & & & & & $\begin{array}{c}-0.5709 * * * \\
(0.0589)\end{array}$ & $\begin{array}{c}-0.1201 * * * \\
(0.0275)\end{array}$ \\
\hline Career dummies & Yes & Yes & No & No & No & No & No \\
\hline Log likelihood & -368502.9 & -289475.34 & -369413.66 & -57040.482 & -312273.81 & -34708.619 & -212804.15 \\
\hline Observations & 153,425 & 111,962 & 153,425 & 36,951 & 116,474 & 17,999 & 66,327 \\
\hline
\end{tabular}

Notes: Poisson estimates without individual fixed effects; Robust standard errors are in parentheses;

$* * * p<0.01, * * p<0.05, * p<0.1$. 
Table E.4: Age of Children (RW Index)

\begin{tabular}{lcccc}
\hline \hline & $(1)$ & $(2)$ & $(3)$ & $(4)$ \\
Variables & All & All & $\begin{array}{c}\text { Women with } \\
\text { children }\end{array}$ & $\begin{array}{c}\text { Men with } \\
\text { children }\end{array}$ \\
\hline Children & -0.1153 & -0.0290 & $-0.1480 *$ & -0.0301 \\
& $(0.0710)$ & $(0.0279)$ & $(0.0732)$ & $(0.0283)$ \\
Teenager & 0.0593 & 0.0164 & 0.0438 & 0.0217 \\
& $(0.0917)$ & $(0.0394)$ & $(0.0949)$ & $(0.0403)$ \\
Twen_plus & -0.0440 & -0.0765 & 0.0310 & -0.0268 \\
& $(0.1996)$ & $(0.1053)$ & $(0.1951)$ & $(0.1031)$ \\
Tenured & $-0.4227 * * *$ & $-0.2662 * * *$ & $-0.4174 * * *$ & $-0.2696 * * *$ \\
& $(0.0837)$ & $(0.0394)$ & $(0.0989)$ & $(0.0439)$ \\
\hline Log likelihood & -25115.626 & -144853.15 & -19569.888 & -112910.54 \\
Observations & 21,618 & 79,280 & 15,578 & 61,166 \\
Individuals & 1,191 & 3,632 & 8,41 & 2,738 \\
\hline \hline
\end{tabular}

Notes: Poisson estimates with individual fixed effects; career year controls (fifth-order polynomial) included; Robust standard errors are in parentheses; $* * * p<0.01, * * p<0.05, * p<0.1$.

Table E.5: Age of CHILDREN (CF INDEX)

\begin{tabular}{lcccc}
\hline \hline & $(1)$ & $(2)$ & $(3)$ & $(4)$ \\
Variables & All & All & $\begin{array}{c}\text { Women with } \\
\text { children }\end{array}$ & $\begin{array}{c}\text { Men with } \\
\text { children }\end{array}$ \\
\hline Children & $-0.1045^{*}$ & $-0.0395^{*}$ & $-0.1083^{*}$ & -0.0361 \\
& $(0.0517)$ & $(0.0227)$ & $(0.0550)$ & $(0.0229)$ \\
Teenager & 0.0447 & -0.0082 & 0.0795 & 0.0082 \\
& $(0.0766)$ & $(0.0313)$ & $(0.0809)$ & $(0.0309)$ \\
Twen_plus & -0.2134 & -0.0562 & -0.0896 & 0.0006 \\
& $(0.1730)$ & $(0.0841)$ & $(0.1828)$ & $(0.0791)$ \\
Tenured & $-0.4157 * * *$ & $-0.2217^{* * *}$ & $-0.4139 * * *$ & $-0.2316 * * *$ \\
& $(0.0677)$ & $(0.0329)$ & $(0.0806)$ & $(0.0373)$ \\
\hline Log likelihood & -212365.5 & -1096399.6 & -162167.15 & -856129.69 \\
Observations & 20,370 & 76,513 & 14,688 & 59,223 \\
Individuals & 1,105 & 3,464 & 785 & 2,624 \\
\hline \hline
\end{tabular}

Notes: Poisson estimates with individual fixed effects; career year controls (fifth-order polynomial) included; Robust standard errors are in parentheses; $* * * p<0.01, * * p<0.05, * p<0.1$. 
Table E.6: AgE OF CHILDREN (RF INDEX)

\begin{tabular}{lcccc}
\hline \hline & $(1)$ & $(2)$ & $(3)$ & $(4)$ \\
Variables & All & All & $\begin{array}{c}\text { Women with } \\
\text { children }\end{array}$ & $\begin{array}{c}\text { Men with } \\
\text { children }\end{array}$ \\
\hline Children & -0.0600 & -0.0289 & -0.0809 & -0.0223 \\
& $(0.0673)$ & $(0.0275)$ & $(0.0713)$ & $(0.0278)$ \\
Teenager & 0.1123 & -0.0230 & 0.1104 & -0.0090 \\
& $(0.0927)$ & $(0.0389)$ & $(0.0963)$ & $(0.0385)$ \\
Twen_plus & -0.0742 & -0.1172 & 0.0027 & -0.0626 \\
& $(0.2011)$ & $(0.1002)$ & $(0.1986)$ & $(0.0973)$ \\
Tenured & $0.4748^{* * *}$ & $-0.2255^{* * *}$ & $-0.4506 * * *$ & $-0.2408^{* * *}$ \\
& $(0.0866)$ & $(0.0400)$ & $(0.1039)$ & $(0.0444)$ \\
\hline Log likelihood & -26507.169 & -138103.72 & -18378.525 & -107803.05 \\
Observations & 21,607 & 79,214 & 15,567 & 61,116 \\
Individuals & 1,191 & 3,625 & 841 & 2,733 \\
\hline \hline
\end{tabular}

Notes: Poisson estimates with individual fixed effects; career year controls (fifth-order polynomial) included; Robust standard errors are in parentheses; $* * * p<0.01, * * p<0.05, * p<0.1$.

Table E.7: NUMBER OF CHILDREN (RW INDEX)

\begin{tabular}{lcccc}
\hline \hline & $(1)$ & $(2)$ & $(3)$ & $(4)$ \\
Variables & All & Men & $\begin{array}{c}\text { Women with } \\
\text { children }\end{array}$ & $\begin{array}{c}\text { Men with } \\
\text { children }\end{array}$ \\
\hline 1_child & -0.0119 & -0.0228 & -0.0957 & -0.0234 \\
& $(0.0867)$ & $(0.0479)$ & $(0.0923)$ & $(0.0539)$ \\
2_children & -0.0380 & -0.0004 & -0.1662 & 0.0079 \\
& $(0.1079)$ & $(0.0545)$ & $(0.1203)$ & $(0.0615)$ \\
3_children & -0.2144 & 0.0109 & $-0.3753^{* *}$ & 0.0152 \\
& $(0.1691)$ & $(0.0774)$ & $(0.1785)$ & $(0.0885)$ \\
All_13_plus & 0.0589 & 0.0165 & -0.0381 & 0.0380 \\
& $(0.1198)$ & $(0.0620)$ & $(0.1287)$ & $(0.0633)$ \\
Tenured & $-0.4271 * * *$ & $-0.2666 * * *$ & $-0.4184 * * *$ & $-0.2714 * * *$ \\
& $(0.0840)$ & $(0.0392)$ & $(0.0991)$ & $(0.0437)$ \\
\hline Log likelihood & -25121.26 & -144867.79 & -19567.891 & -112914.85 \\
Observations & 21,618 & 79,280 & 15,578 & 61,166 \\
Individuals & 1,191 & 3,632 & 841 & 2,738 \\
\hline \hline
\end{tabular}

Notes: Poisson estimates with individual fixed effects; career year controls (fifth-order polynomial) included; Robust standard errors are in parentheses; *** $p<0.01$, ** $p<0.05$, * $p<0.1$. 
Table E.8: Number of CHILDREN (CF InDEX)

\begin{tabular}{lcccc}
\hline \hline & $(1)$ & $(2)$ & $(3)$ & $(4)$ \\
Variables & All & All & $\begin{array}{c}\text { Women with } \\
\text { children }\end{array}$ & $\begin{array}{c}\text { Men with } \\
\text { children }\end{array}$ \\
\hline 1_child & $0.1282^{*}$ & 0.0410 & 0.0839 & 0.0284 \\
& $(0.0683)$ & $(0.0404)$ & $(0.0745)$ & $(0.0453)$ \\
2_children & -0.0848 & 0.0392 & -0.1324 & 0.0378 \\
& $(0.0883)$ & $(0.0446)$ & $(0.0999)$ & $(0.0499)$ \\
3_children & $-0.2827 * *$ & 0.0433 & $-0.3266 * *$ & 0.0499 \\
& $(0.1289)$ & $(0.0631)$ & $(0.1397)$ & $(0.0720)$ \\
all_13_plus & 0.0129 & 0.0443 & 0.0185 & 0.0665 \\
& $(0.1028)$ & $(0.0510)$ & $(0.1114)$ & $(0.0530)$ \\
tenured & $-0.4139 * * *$ & $-0.2249 * * *$ & $-0.4114 * * *$ & $-0.2358 * * *$ \\
& $(0.0677)$ & $(0.0327)$ & $(0.0806)$ & $(0.0370)$ \\
\hline Log likelihood & -212135.95 & -1096476.3 & -161920.33 & -856173.52 \\
Observations & 20,370 & 76,513 & 14,688 & 59,223 \\
Individuals & 1,105 & 3,464 & 785 & 2,624 \\
\hline \hline
\end{tabular}

Notes: Poisson estimates with individual fixed effects; career year controls (fifth-order polynomial) included; Robust standard errors are in parentheses; $* * * p<0.01, * * p<0.05, * p<0.1$. 
Table E.9: Number of CHILDREN (RF INDEX)

\begin{tabular}{lcccc}
\hline \hline & $(1)$ & $(2)$ & $(3)$ & $(4)$ \\
Variables & All & All & $\begin{array}{c}\text { Women with } \\
\text { children }\end{array}$ & $\begin{array}{c}\text { Men with } \\
\text { children }\end{array}$ \\
\hline 1_child & $0.1694 * *$ & 0.0105 & 0.0972 & -0.0025 \\
& $(0.0818)$ & $(0.0483)$ & $(0.0880)$ & $(0.0541)$ \\
2_children & -0.0082 & 0.0365 & -0.1062 & 0.0420 \\
& $(0.1109)$ & $(0.0550)$ & $(0.1260)$ & $(0.0612)$ \\
3_children & -0.2525 & 0.0246 & $-0.3693 * *$ & 0.0443 \\
& $(0.1648)$ & $(0.0790)$ & $(0.1774)$ & $(0.0903)$ \\
all_13_plus & 0.1277 & 0.0058 & 0.0604 & 0.0335 \\
& $(0.1235)$ & $(0.0625)$ & $(0.1341)$ & $(0.0631)$ \\
tenured & $-0.4702 * * *$ & $-0.2276 * * *$ & $-0.4436^{* * *}$ & $-0.2438 * * *$ \\
& $(0.0870)$ & $(0.0399)$ & $(0.1044)$ & $(0.0442)$ \\
\hline Log likelihood & -23473.997 & -138117.88 & -18344.966 & -107801.81 \\
Observations & 21,607 & 79,214 & 15,567 & 61,116 \\
Individuals & 1,191 & 3,625 & 841 & 2,733 \\
\hline \hline
\end{tabular}

Notes: Poisson estimates with individual fixed effects; career year controls (fifth-order polynomial) included; Robust standard errors are in parentheses; $* * * p<0.01, * * p<0.05, * p<0.1$.

Table E.10: The EFFECT Of TwINS (RW INDEX)

\begin{tabular}{lcccc}
\hline \hline & $(1)$ & $(2)$ & $(3)$ & $(4)$ \\
Variables & Women & Men & Mothers & Fathers \\
\hline Twins & -0.1023 & $0.4212^{* *}$ & -0.1908 & $0.4190^{* *}$ \\
& $(0.3607)$ & $(0.1987)$ & $(0.3582)$ & $(0.2000)$ \\
\hline Log pseudolikelihood & -25127.007 & -144786.15 & -19575.236 & -112833.77 \\
Observations & 21,618 & 79,280 & 15,578 & 61,166 \\
Individuals & 1,191 & 3,632 & 841 & 2,738 \\
\hline \hline
\end{tabular}

Notes: Poisson estimates with individual fixed effects; career year controls

(fifth-order polynomial) included; Robust standard errors are in parentheses; $* * * p<0.01, * * p<0.05, * p<0.1$. 
Table E.11: The EFFECT OF TwINs (CF INDEX)

\begin{tabular}{lcccc}
\hline \hline & $(1)$ & $(2)$ & $(3)$ & $(4)$ \\
Variables & Women & Men & Mothers & Fathers \\
\hline Twins & -0.1522 & $0.5127^{* * *}$ & -0.1784 & $0.5118^{* * *}$ \\
& $(0.2251)$ & $(0.1692)$ & $(0.2221)$ & $(0.1701)$ \\
\hline Log pseudolikelihood & -212174.43 & -1095387 & -161957.4 & -855083.34 \\
Observations & 20,370 & 76,513 & 14,688 & 59,223 \\
Individuals & 1,105 & 3,464 & 785 & 2,624 \\
\hline \hline
\end{tabular}

Notes: Poisson estimates with individual fixed effects; career year controls (fifth-order polynomial) included; Robust standard errors are in parentheses; $* * * p<0.01, * * p<0.05, * p<0.1$.

Table E.12: THE EFFeCT OF TWINS (RF INDEX)

\begin{tabular}{lcccc}
\hline \hline & $(1)$ & $(2)$ & $(3)$ & $(4)$ \\
Variables & Women & Men & Mothers & Fathers \\
\hline Twins & -0.1790 & $0.4979^{* *}$ & -0.2417 & $0.5027^{* *}$ \\
& $(0.2931)$ & $(0.1977)$ & $(0.2917)$ & $(0.1990)$ \\
\hline Log pseudolikelihood & -23497.255 & -138016.42 & -18351.282 & -107702.82 \\
Observations & 21,607 & 79,214 & 15,567 & 61,117 \\
Individuals & 1,191 & 3,625 & 841 & 2,733 \\
\hline \hline
\end{tabular}

Notes: Poisson estimates with individual fixed effects; career year controls (fifth-order polynomial) included; Robust standard errors are in parentheses; $* * * p<0.01, * * p<0.05, * p<0.1$. 
Table E.13: SEMiparametric Difference-In-Difference Estimates of the EFFECT OF PARENThood For Women (RW INDEX)

\begin{tabular}{|c|c|c|c|c|c|c|c|c|c|c|c|}
\hline Variables & $(1)$ & $(2)$ & (3) & (4) & (5) & (6) & (7) & (8) & (9) & $(10)$ & $(11)$ \\
\hline \multirow[t]{2}{*}{ Constant } & -0.1030 & -0.4778 & -0.4742 & -0.2716 & 0.0560 & 0.2844 & 0.3270 & $-1.1646^{* *}$ & $-1.0773 *$ & -1.3240 & -2.1291 \\
\hline & $(0.4895)$ & $(0.7196)$ & $(0.8577)$ & $(0.8096)$ & $(0.3993)$ & $(0.5590)$ & $(0.3120)$ & $(0.5412)$ & $(0.5941)$ & $(1.4410)$ & $(2.0351)$ \\
\hline \multirow[t]{2}{*}{ Married } & & 0.4024 & 0.4095 & & & & & & & & 0.7864 \\
\hline & & $(0.9049)$ & $(0.9359)$ & & & & & & & & $(0.9462)$ \\
\hline \multirow[t]{2}{*}{ Spouse college } & & & -0.0111 & & & & & & & & -0.8054 \\
\hline & & & $(1.0761)$ & & & & & & & & $(1.1620)$ \\
\hline \multirow[t]{2}{*}{ Day care available } & & & & 0.1248 & & & & & & & -0.0729 \\
\hline & & & & $(1.0643)$ & & & & & & & $(0.9804)$ \\
\hline \multirow[t]{2}{*}{ Day care unavailable } & & & & 0.8038 & & & & & & & 0.4690 \\
\hline & & & & $(1.2616)$ & & & & & & & $(1.2944)$ \\
\hline \multirow[t]{2}{*}{$\mathrm{PhD}$} & & & & & -0.2031 & & & & -0.1205 & & 0.0135 \\
\hline & & & & & $(0.7406)$ & & & & $(0.7640)$ & & $(0.7053)$ \\
\hline \multirow[t]{2}{*}{ Tenured } & & & & & & $-2.1204 *$ & & & -1.6604 & & -1.3511 \\
\hline & & & & & & (1.1907) & & & $(1.4390)$ & & $(1.4618)$ \\
\hline \multirow[t]{2}{*}{ Top quartile } & & & & & & & -1.4351 & & & & -1.1503 \\
\hline & & & & & & & $(1.4624)$ & & & & $(1.5169)$ \\
\hline \multirow[t]{2}{*}{ Age $30-34$ yr } & & & & & & & & $2.4582 * *$ & $2.6719 * * *$ & & $2.7724 * * *$ \\
\hline & & & & & & & & $(0.9752)$ & $(0.8859)$ & & $(0.8298)$ \\
\hline \multirow[t]{2}{*}{ Age $35+$ yr } & & & & & & & & -0.4012 & 0.2151 & & 0.4201 \\
\hline & & & & & & & & $(1.0808)$ & $(1.3182)$ & & $(1.3402)$ \\
\hline \multirow[t]{2}{*}{ European PhD } & & & & & & & & & & 1.1422 & 1.1157 \\
\hline & & & & & & & & & & (1.5074) & $(1.4940)$ \\
\hline \multirow[t]{2}{*}{ N. American PhD } & & & & & & & & & & 1.5424 & 1.3332 \\
\hline & & & & & & & & & & (1.9572) & (1.8503) \\
\hline Observations & 665 & 665 & 665 & 665 & 665 & 665 & 665 & 665 & 665 & 665 & 665 \\
\hline
\end{tabular}

Notes: $K=2$; Robust standard errors are in parentheses; *** $p<0.01, * * p<0.05, * p<0.1$. 
Table E.14: Semiparametric Difference-In-Difference Estimates of the EfFect of Parenthood fOr Men (RW Index)

\begin{tabular}{|c|c|c|c|c|c|c|c|c|c|c|c|}
\hline Variables & $(1)$ & $(2)$ & (3) & $(4)$ & $(5)$ & (6) & (7) & $(8)$ & (9) & $(10)$ & $(11)$ \\
\hline \multirow[t]{2}{*}{ Constant } & $0.8306^{*}$ & 0.6634 & 1.5437 & $1.2754 * *$ & 0.2944 & $1.1280 * *$ & $0.5628^{*}$ & 0.1508 & -0.0749 & 0.0362 & 1.0273 \\
\hline & $(0.4493)$ & $(0.8024)$ & $(0.9671)$ & $(0.6429)$ & $(0.4003)$ & $(0.4980)$ & $(0.3187)$ & (0.8088) & $(0.7306)$ & $(0.2546)$ & (1.3910) \\
\hline \multirow[t]{2}{*}{ Married } & & 0.1819 & 1.1744 & & & & & & & & 1.1395 \\
\hline & & $(0.9479)$ & $(1.2415)$ & & & & & & & & (1.1989) \\
\hline \multirow[t]{2}{*}{ Spouse college } & & & -2.0107 & & & & & & & & -2.2310 \\
\hline & & & $(1.4528)$ & & & & & & & & (1.4157) \\
\hline \multirow[t]{2}{*}{ Day care available } & & & & -0.4661 & & & & & & & -0.8271 \\
\hline & & & & $(0.8432)$ & & & & & & & $(0.7902)$ \\
\hline \multirow[t]{2}{*}{ Day care unavailable } & & & & -0.7666 & & & & & & & -1.1864 \\
\hline & & & & $(1.3721)$ & & & & & & & (1.4023) \\
\hline \multirow[t]{2}{*}{$\mathrm{PhD}$} & & & & & 0.7275 & & & & 0.8662 & & 0.5348 \\
\hline & & & & & $(0.7194)$ & & & & $(0.9278)$ & & $(0.8381)$ \\
\hline \multirow[t]{2}{*}{ Tenured } & & & & & & -1.3474 & & & -1.6864 & & -1.7294 \\
\hline & & & & & & (1.1875) & & & (1.2378) & & (1.2469) \\
\hline \multirow[t]{2}{*}{ Top quartile } & & & & & & & 0.9622 & & & & 1.0702 \\
\hline & & & & & & & (1.4057) & & & & $(1.4050)$ \\
\hline \multirow[t]{2}{*}{ Age $30-34$ yr } & & & & & & & & 1.0889 & 0.8770 & & 0.8819 \\
\hline & & & & & & & & (1.0717) & $(1.1612)$ & & (1.1770) \\
\hline \multirow[t]{2}{*}{ Age $35+$ yr } & & & & & & & & 0.5582 & 0.6807 & & 0.4152 \\
\hline & & & & & & & & (1.1467) & (1.3914) & & (1.4298) \\
\hline \multirow[t]{2}{*}{ European PhD } & & & & & & & & & & 0.5340 & 0.4842 \\
\hline & & & & & & & & & & $(0.4751)$ & $(0.4966)$ \\
\hline \multirow[t]{2}{*}{ N. American $\mathrm{PhD}$} & & & & & & & & & & 1.3905 & 1.1199 \\
\hline & & & & & & & & & & $(1.1384)$ & $(0.9630)$ \\
\hline Observations & 1,459 & 1,459 & 1,459 & 1,459 & 1,459 & 1,459 & 1,459 & 1,459 & 1,459 & 1,459 & 1,459 \\
\hline
\end{tabular}

Notes: $K=4$; Robust standard errors are in parentheses; $* * * p<0.01, * * p<0.05, * p<0.1$. 
Table E.15: Semiparametric Difference-In-Difference Estimates of the EFfeCt of Parenthood For Women (CF IndeX)

\begin{tabular}{|c|c|c|c|c|c|c|c|c|c|c|c|}
\hline Variables & (1) & (2) & (3) & (4) & (5) & (6) & (7) & (8) & (9) & $(10)$ & $(11)$ \\
\hline Constant & $\begin{array}{c}4.4502 \\
(4.1216)\end{array}$ & $\begin{array}{c}-24.0850^{* * *} \\
(7.0744)\end{array}$ & $\begin{array}{c}-32.3511 * * * \\
(8.1961)\end{array}$ & $\begin{array}{l}-4.7993 \\
(7.9638)\end{array}$ & $\begin{array}{l}-2.0689 \\
(4.5667)\end{array}$ & $\begin{array}{c}4.5601 \\
(4.3561)\end{array}$ & $\begin{array}{c}2.1358 \\
(3.6180)\end{array}$ & $\begin{array}{l}-8.7690 * \\
(4.7603)\end{array}$ & $\begin{array}{c}-10.5000 * \\
(5.8097)\end{array}$ & $\begin{array}{c}9.3137 \\
(7.0475)\end{array}$ & $\begin{array}{c}-48.0447 * * * \\
(16.6289)\end{array}$ \\
\hline Married & & $\begin{array}{c}30.6306^{* * *} \\
(8.4727)\end{array}$ & $\begin{array}{c}14.5254 \\
(11.9916)\end{array}$ & & & & & & & & $\begin{array}{c}13.6380 \\
(11.8115)\end{array}$ \\
\hline Spouse college & & & $\begin{array}{l}25.2932 * \\
(14.0860)\end{array}$ & & & & & & & & $\begin{array}{l}26.4412 * \\
(14.0529)\end{array}$ \\
\hline Day care available & & & & $\begin{array}{l}12.6116 \\
(9.6350)\end{array}$ & & & & & & & $\begin{array}{l}11.8479 \\
(9.3236)\end{array}$ \\
\hline Day care unavailable & & & & $\begin{array}{c}-2.2179 \\
(10.7570)\end{array}$ & & & & & & & $\begin{array}{c}-3.2026 \\
(10.8916)\end{array}$ \\
\hline $\mathrm{PhD}$ & & & & & $\begin{array}{c}8.3319 \\
(7.0330)\end{array}$ & & & & $\begin{array}{c}4.2263 \\
(6.9648)\end{array}$ & & $\begin{array}{c}3.6431 \\
(6.8703)\end{array}$ \\
\hline Tenured & & & & & & $\begin{array}{c}-0.6020 \\
(13.0257)\end{array}$ & & & $\begin{array}{c}-2.4793 \\
(14.6917)\end{array}$ & & $\begin{array}{c}-6.0244 \\
(14.8998)\end{array}$ \\
\hline Top quartile & & & & & & & $\begin{array}{c}8.1665 \\
(11.7669)\end{array}$ & & & & $\begin{array}{c}9.1464 \\
(12.3792)\end{array}$ \\
\hline Age $30-34$ yr & & & & & & & & $\begin{array}{c}18.4378 * * \\
(8.5147)\end{array}$ & $\begin{array}{c}17.0939 * * \\
(7.6080)\end{array}$ & & $\begin{array}{c}15.5407 * * \\
(7.2457)\end{array}$ \\
\hline Age $35+\mathrm{yr}$ & & & & & & & & $\begin{array}{l}12.6782 \\
(9.0940)\end{array}$ & $\begin{array}{c}11.2777 \\
(10.6941)\end{array}$ & & $\begin{array}{c}9.6781 \\
(10.9871)\end{array}$ \\
\hline European $\mathrm{PhD}$ & & & & & & & & & & $\begin{array}{l}-5.3929 \\
(8.1002)\end{array}$ & $\begin{array}{l}-7.0743 \\
(8.3832)\end{array}$ \\
\hline N. American $\mathrm{PhD}$ & & & & & & & & & & $\begin{array}{c}-4.4949 \\
(12.4608)\end{array}$ & $\begin{array}{l}-11.7257 \\
(12.1384)\end{array}$ \\
\hline Observations & 665 & 665 & 665 & 665 & 665 & 665 & 665 & 665 & 665 & 665 & 665 \\
\hline
\end{tabular}

Notes: $K=2$; Robust standard errors are in parentheses; *** $p<0.01, * * p<0.05, * p<0.1$. 
Table E.16: Semiparametric Difference-in-Difference Estimates of the EFFECt of Parenthood for Men (CF Index)

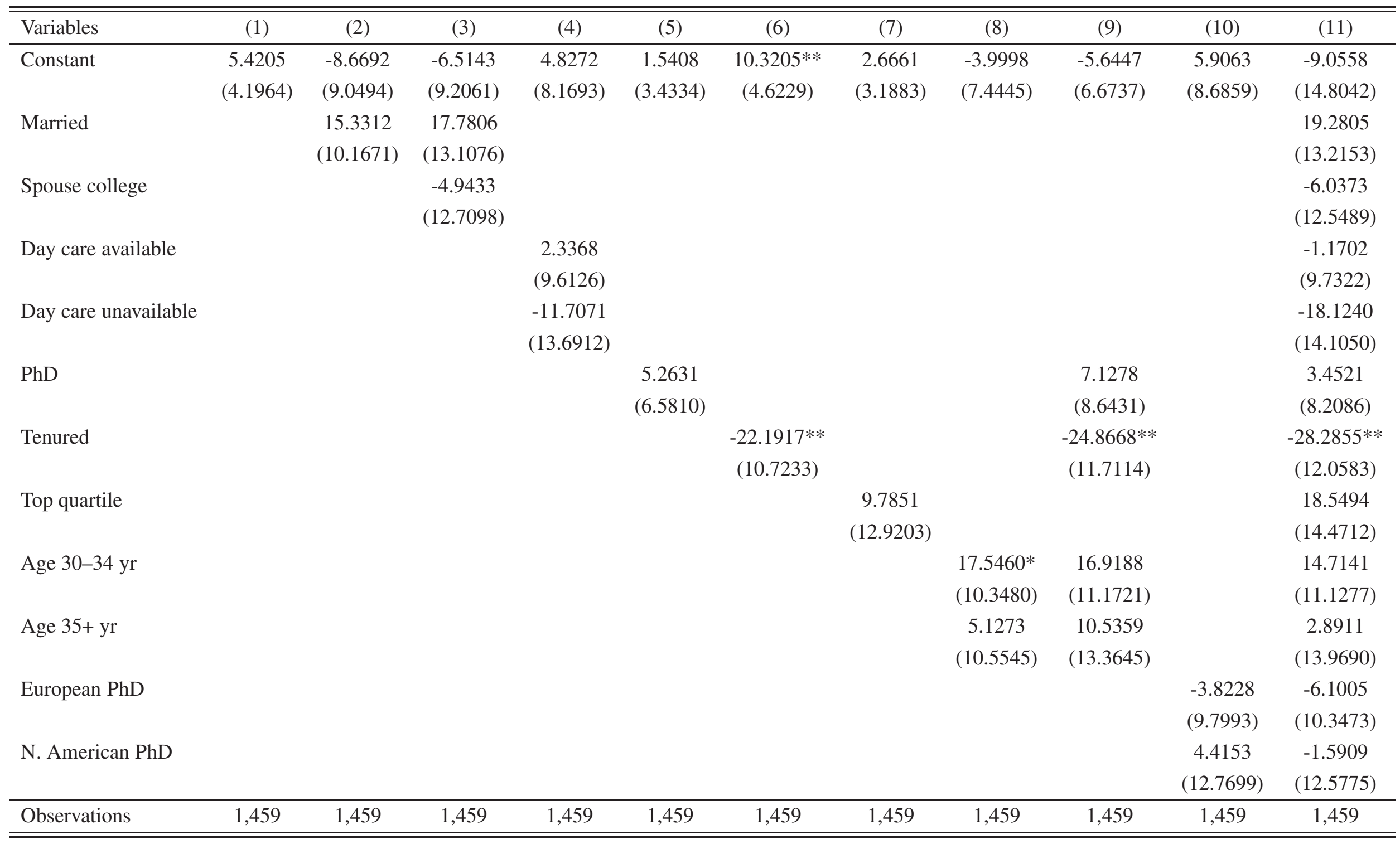

Notes: $K=4$; Robust standard errors are in parentheses; *** $p<0.01, * * p<0.05, * p<0.1$. 
Table E.17: Semiparametric DifFerence-In-DifFerence Estimates of the EFFeCt of Parenthood FOR Women (RF IndeX)

\begin{tabular}{|c|c|c|c|c|c|c|c|c|c|c|c|}
\hline Variables & $(1)$ & (2) & (3) & (4) & $(5)$ & $(6)$ & $(7)$ & (8) & (9) & $(10)$ & (11) \\
\hline Constant & $\begin{array}{c}0.6442 \\
(0.5124)\end{array}$ & $\begin{array}{l}-1.6969 * \\
(0.8856)\end{array}$ & $\begin{array}{c}-2.6656^{* * * *} \\
(0.9712)\end{array}$ & $\begin{array}{c}0.8823 \\
(0.8129)\end{array}$ & $\begin{array}{c}0.1124 \\
(0.4829)\end{array}$ & $\begin{array}{c}0.8609 \\
(0.5262)\end{array}$ & $\begin{array}{c}0.4563 \\
(0.4024)\end{array}$ & $\begin{array}{c}-0.9310 * * \\
(0.3859)\end{array}$ & $\begin{array}{c}-1.1080 * * \\
(0.5309)\end{array}$ & $\begin{array}{l}-0.1070 \\
(0.2512)\end{array}$ & $\begin{array}{c}-4.1018 * * \\
(1.8182)\end{array}$ \\
\hline Married & & $\begin{array}{c}2.5140 * * \\
(1.0516)\end{array}$ & $\begin{array}{c}0.6130 \\
(1.4069)\end{array}$ & & & & & & & & $\begin{array}{c}0.6285 \\
(1.3997)\end{array}$ \\
\hline Spouse college & & & $\begin{array}{c}2.9790 * * \\
(1.4862)\end{array}$ & & & & & & & & $\begin{array}{l}2.8269^{*} \\
(1.4875)\end{array}$ \\
\hline Day care available & & & & $\begin{array}{c}-0.1542 \\
(1.0534)\end{array}$ & & & & & & & $\begin{array}{l}-0.3545 \\
(0.9709)\end{array}$ \\
\hline Day care unavailable & & & & $\begin{array}{l}-1.3117 \\
(1.2181)\end{array}$ & & & & & & & $\begin{array}{l}-1.5792 \\
(1.2148)\end{array}$ \\
\hline $\mathrm{PhD}$ & & & & & $\begin{array}{c}0.6793 \\
(0.8140)\end{array}$ & & & & $\begin{array}{c}0.4768 \\
(0.8247)\end{array}$ & & $\begin{array}{c}0.3307 \\
(0.7752)\end{array}$ \\
\hline Tenured & & & & & & $\begin{array}{l}-1.1874 \\
(1.6104)\end{array}$ & & & $\begin{array}{l}-1.0474 \\
(1.8834)\end{array}$ & & $\begin{array}{l}-1.4095 \\
(1.9226)\end{array}$ \\
\hline Top quartile & & & & & & & $\begin{array}{c}0.6306 \\
(1.4934)\end{array}$ & & & & $\begin{array}{c}1.0106 \\
(1.5627)\end{array}$ \\
\hline Age $30-34$ yr & & & & & & & & $\begin{array}{c}2.7851 * * * \\
(0.9793)\end{array}$ & $\begin{array}{c}2.7088^{* * *} \\
(0.8249)\end{array}$ & & $\begin{array}{c}2.5261 * * * \\
(0.7248)\end{array}$ \\
\hline Age $35+\mathrm{yr}$ & & & & & & & & $\begin{array}{c}0.6570 \\
(0.9282)\end{array}$ & $\begin{array}{c}0.7526 \\
(1.2209)\end{array}$ & & $\begin{array}{c}0.5571 \\
(1.3922)\end{array}$ \\
\hline European $\mathrm{PhD}$ & & & & & & & & & & $\begin{array}{c}0.6642 \\
(0.5243)\end{array}$ & $\begin{array}{c}0.3430 \\
(0.6199)\end{array}$ \\
\hline N. American PhD & & & & & & & & & & $\begin{array}{c}1.0239 \\
(1.3291)\end{array}$ & $\begin{array}{c}0.1229 \\
(1.3161)\end{array}$ \\
\hline Observations & 665 & 665 & 665 & 665 & 665 & 665 & 665 & 665 & 665 & 665 & 665 \\
\hline
\end{tabular}

Notes: $K=2$; *** $p<0.01, * * p<0.05, * p<0.1$. 
Table E.18: Semiparametric Difference-in-Difference Estimates of the EFFECt of Parenthood for Men (RF Index)

\begin{tabular}{|c|c|c|c|c|c|c|c|c|c|c|c|}
\hline Variables & (1) & (2) & (3) & (4) & (5) & (6) & (7) & (8) & (9) & (10) & (11) \\
\hline \multirow[t]{2}{*}{ Constant } & 0.5856 & -0.2254 & 0.0716 & 0.2267 & 0.3755 & $1.2654 * *$ & 0.4450 & 0.0709 & -0.0747 & 0.5047 & -0.3219 \\
\hline & $(0.4870)$ & $(0.9084)$ & $(1.0842)$ & (1.0824) & $(0.3597)$ & $(0.5514)$ & $(0.3371)$ & $(0.6993)$ & $(0.6783)$ & $(0.6458)$ & (1.6298) \\
\hline \multirow[t]{2}{*}{ Married } & & 0.8822 & 1.2179 & & & & & & & & 1.3546 \\
\hline & & $(1.0540)$ & $(1.4735)$ & & & & & & & & $(1.4657)$ \\
\hline \multirow[t]{2}{*}{ Spouse college } & & & -0.6792 & & & & & & & & -0.7067 \\
\hline & & & $(1.7452)$ & & & & & & & & $(1.7267)$ \\
\hline \multirow[t]{2}{*}{ Day care available } & & & & 0.5581 & & & & & & & 0.2489 \\
\hline & & & & $(1.2312)$ & & & & & & & $(1.2435)$ \\
\hline \multirow[t]{2}{*}{ Day care unavailable } & & & & -0.7339 & & & & & & & -1.3255 \\
\hline & & & & $(1.5071)$ & & & & & & & $(1.5797)$ \\
\hline \multirow[t]{2}{*}{$\mathrm{PhD}$} & & & & & 0.2850 & & & & 0.7157 & & 0.4176 \\
\hline & & & & & $(0.7451)$ & & & & $(0.8704)$ & & $(0.7593)$ \\
\hline \multirow[t]{2}{*}{ Tenured } & & & & & & $-3.0767 * * *$ & & & $-3.4833 * * *$ & & $-3.6695 * * *$ \\
\hline & & & & & & $(1.1541)$ & & & $(1.2991)$ & & $(1.3418)$ \\
\hline \multirow[t]{2}{*}{ Top quartile } & & & & & & & 0.4967 & & & & 1.3267 \\
\hline & & & & & & & $(1.5322)$ & & & & $(1.7208)$ \\
\hline \multirow[t]{2}{*}{ Age $30-34 \mathrm{yr}$} & & & & & & & & 1.1113 & 1.1439 & & 1.0360 \\
\hline & & & & & & & & $(1.0881)$ & (1.0392) & & (1.0311) \\
\hline \multirow[t]{2}{*}{ Age $35+$ yr } & & & & & & & & 0.1182 & 1.0606 & & 0.5291 \\
\hline & & & & & & & & (1.0950) & $(1.3052)$ & & (1.3708) \\
\hline \multirow[t]{2}{*}{ European PhD } & & & & & & & & & & -0.3171 & -0.5420 \\
\hline & & & & & & & & & & $(0.7772)$ & $(0.8711)$ \\
\hline \multirow[t]{2}{*}{ N. American $\mathrm{PhD}$} & & & & & & & & & & 0.7011 & 0.0385 \\
\hline & & & & & & & & & & $(1.3387)$ & $(1.2152)$ \\
\hline Observations & 1,459 & 1,459 & 1,459 & 1,459 & 1,459 & 1,459 & 1,459 & 1,459 & 1,459 & 1,459 & 1,459 \\
\hline
\end{tabular}

Notes: $K=4$; Robust standard errors are in parentheses; *** $p<0.01, * * p<0.05$, * $p<0.1$. 